\title{
Educação em Ciências e Pensamento Bakhtiniano: Uma Análise de Trabalhos Publicados em Periódicos Nacionais
}

\section{Science Education and Bakhtinian Thought: An Analysis of Papers Published in National Journals}

\section{Diomar Caríssimo Selli Deconto Brasil Fernanda Ostermann Brasil}

Neste trabalho desenvolvemos uma análise da produção da área de Educação em Ciências relacionada ao pensamento bakhtiniano. Com o objetivo de compreender como esse pensamento tem sido incorporado à área no Brasil, realizamos levantamento, sistematização e análise de trabalhos publicados em periódicos nacionais voltados à Educação em Ciências. Nossas análises apontam quantitativos de produção, dados referentes à origem do pensamento bakhtiniano na área, bem como a caracterização dessa produção quanto aos periódicos, às instituições de origem, principais pesquisadores, natureza de investigação e linhas temáticas. Nossas análises debruçam-se também sobre algumas questões conceituais e metodológicas que envolvem essa produção, de forma a compor uma interpretação de como se constitui o pensamento bakhtiniano na Educação em Ciências. Identificamos trabalhos bastante consistentes, mas também muitas apropriações marcadas pela banalização e deturpação de alguns conceitos, por fragilidades metodológicas resultantes da interpretação do pensamento bakhtiniano como método e por análises mecânicas e superficiais. Percebe-se que há uma tendência de aplicar as ideias do Círculo bakhtiniano, ao invés de pensar a partir delas.

Palavras-chave: Bakhtin; Estado da arte; Educação em Ciências.

In this paper, we develop an analysis of the production in the field of science education according to the Bakhtinian thought. In order to understand how Bakhtin's theoretical framework has been incorporated in studies on science education studies in Brazil, we conducted a survey, systematization and analysis of papers published in Brazilian journals focused on science education. Our analyzes indicate quantitative production, data referring to the origin of Bakhtinian thought in the field, as well as the characterization of this production regarding the journals, the institutions of origin, main researchers, research nature and thematic approaches. Additionally, our analyzes also focus on some conceptual and methodological issues that involve this production, in order to compose an interpretation of how the Bakhtinian thought is constituted in science education. Therefore, we highlight that there are quite consistent appropriations, but also many 
approaches characterized by the trivialization and misrepresentation of some concepts, by methodological weaknesses resulting from the interpretation of Bakhtinian thought as a method and by mechanical and superficial analyzes. We noticed that there is a tendency to apply the ideas of the Bakhtinian Circle, instead of thinking from them.

Keywords: Bakhtin; State of the art; Science education.

\section{Introdução}

A área de Educação em Ciências no Brasil tem sido apontada por seus principais pesquisadores como uma área interdisciplinar (Nardi, \& Almeida, 2008), de forma que há sempre algum tipo de interação entre conhecimento específico e de outras áreas, em especial da Educação. Outro campo que tem sido bastante aproximado é o da Linguística, como se pode perceber a partir de apontamentos presentes nos trabalhos de revisão elaborados, a título de exemplo, por Pinhão e Martins (2007), Garcia e Lima (2009), Nicolli, Oliveira e Cassiani (2011), Souza, Silva, Santos e Santos (2013). Esses trabalhos, que tiveram por objetivo analisar produções científicas nacionais referentes, de forma mais geral, à linguagem e à Educação em Ciências e, de maneira mais específica, à análise do discurso e à pesquisa em Educação em Ciências, apontam, de maneira unânime, a predominância de filiações teóricas à perspectiva do "Círculo de Bakhtin"1.

Entretanto, ao mesmo tempo em que este referencial tem se destacado na Educação em Ciências, pouco se sabe sobre sua apropriação por esta área de pesquisa, uma vez que não encontramos na literatura trabalhos dedicados a fazer levantamento, sistematização e análise de artigos produzidos a partir do pensamento bakhtiniano. Assim, diante desses aspectos que apontam a inexistência de olhares críticos para a produção pautada pelo pensamento bakhtiniano na área de Educação em Ciências e pelo fato de entendermos que é de suma importância compreender a forma como este tem permeado-a temos por objetivo apresentar um estado da arte sobre esta temática a partir de artigos publicados em revistas nacionais classificadas no estrato A do Qualis da área de Ensino da CAPES.

\footnotetext{
1 Como explicamos mais adiante, há algumas polêmicas envolvendo a invenção apócrifa "Círculo de Bakhtin”. Por ora, simplesmente apontamos que, ao nos remetermos a este termo, não estaremos atribuindo centralidade a Bakhtin, uma vez que tem sido entendido como equívoco considerar este "mestre" dos demais intelectuais pertencentes ao chamado "Círculo". Desta forma, na ausência de uma expressão melhor, utilizaremos "Círculo bakhtiniano" ou, simplesmente, "Círculo" pelo fato de sua consolidação na literatura, mas considerando que, na verdade, as ideias são do Círculo de que Bakhtin faz parte, constituído pelo pensamento também de outros intelectuais tão importantes quanto ele (Seriot, 2015). Assim, quando estivermos nos referindo ao pensamento bakhtiniano, não se deve entender como pensamento de Bakhtin, mas como um corpus de fundamentos provenientes da constante interlocução entre intelectuais (não apenas, mas principalmente Voloshinov, Medvedev e Bakhtin) com relação a temas, interesses e categorias recorrentes.
} 


\section{Perspectiva metodológica: uma pesquisa do tipo "estado da arte"}

As pesquisas denominadas "estado da arte", segundo Ferreira (2002), são definidas como de caráter bibliográfico, caracterizando-se por buscar mapear e discutir determinado campo do conhecimento. O mesmo autor acrescenta ainda que

Também são reconhecidas por realizarem uma metodologia de caráter inventariante e descritivo da produção acadêmica e científica sobre o tema que busca investigar, à luz de categorias e facetas que se caracterizam enquanto tais em cada trabalho e no conjunto deles, sob os quais o fenômeno passa a ser analisado (Ferreira, 2002, p. 258).

Por outro lado, entendemos que este tipo de pesquisa não deve se limitar à quantificação e descrição de trabalhos. Faz-se necessário, principalmente, evidenciar a dimensão qualitativa que a envolve, em um movimento que culmine na análise crítica/ problematizadora das pesquisas sobre determinado campo de estudo. Neste sentido, consideramos como pouco construtivos os trabalhos com esta metodologia, ou seja, que se limitam a apresentar breves resumos descritivos de cada produção constituinte do corpus da pesquisa ou apenas desenvolver o levantamento da produção sem problematizar o que tem sido por ela apresentado. Desta forma, entendemos que o tipo de pesquisa aqui proposta auxilia na compreensão de como se dá a produção do conhecimento de uma determinada área, no exame de ênfases e temas abordados e dos referenciais teóricometodológicos, bem como sua articulação com o todo da pesquisa. Além disso, permite examinar as contribuições, lacunas, questões problemáticas, proposições e sugestões acerca da referida área de estudo, possibilitando uma visão geral da área (Romanowski, \& Ens, 2006). Assim, o desenvolvimento dessas pesquisas justifica-se, pois

Estados da arte podem significar uma contribuição importante na constituição do campo teórico de uma área de conhecimento, pois procuram identificar os aportes significativos da construção da teoria e prática pedagógica, apontar as restrições sobre o campo em que se move a pesquisa, as suas lacunas de disseminação, identificar experiências inovadoras investigadas que apontem alternativas de solução para os problemas da prática e reconhecer as contribuições da pesquisa na constituição de propostas na área focalizada (Romanowski, \& Ens, 2006, p. 39).

Efetivar, no âmbito metodológico, o que propõe uma pesquisa do tipo "estado da arte" exige que haja, primeiramente, a seleção do corpus, a partir do qual serão desenvolvidas as análises que constituirão a interpretação emergente do estudo. Assim, com o objetivo de compreender como o pensamento bakhtiniano tem sido incorporado pela área de Educação em Ciências no Brasil, a constituição do nosso corpus se deu a partir de revistas nacionais classificadas no estrato A da grande área "Ensino" do Qualis da Capes. Obviamente, esta área engloba revistas de diversas subáreas "Ensino de", sejam elas "Ensino de Saúde", "Ensino de Engenharia" etc., de forma que foi necessário fazer um recorte e selecionar desse grande grupo aquelas nas quais, tradicionalmente, os trabalhos de Educação em Ciências são publicados. Assim, a seleção ocorreu a partir das seguintes revistas: Alexandria: Revista de Educação em Ciência e Tecnologia 
(Alexandria); Amazônia: Revista de Educação em Ciências e Matemáticas (AM); Areté: Revista Amazônica de Ensino de Ciências (Areté); Caderno Brasileiro de Ensino de Física (CBEF); Ciência \& Educação (C\&E); Ensaio: Pesquisa em Educação em Ciências (Ensaio); Investigações em Ensino de Ciências (IENCI); Revista Brasileira de Ensino de Ciência e Tecnologia (RBECT); Revista Brasileira de Ensino de Física (RBEF); Revista Brasileira de Pesquisa em Educação em Ciências (RBPEC) e Revista Práxis (Práxis). Diante de tal seleção, ressaltamos a limitação do nosso trabalho: não se trata de um estudo exaustivo, pois não foram abordados todos os periódicos da área, nem teses e dissertações sobre o tema. Por outro lado, cremos que a relevância apresentada pelos periódicos no contexto da área de Educação em Ciências pode funcionar como um bom parâmetro do que nela ocorre, permitindo vislumbrar aspectos relevantes para compreender como o pensamento bakhtiniano tem sido aproximado à Educação em Ciências, bem como, mesmo que de maneira um pouco mais limitada, refletir sobre possíveis formas de "apropriação" ${ }^{2}$ deste pensamento.

Nestas revistas, buscamos trabalhos que apresentassem os seguintes descritores: Bakhtin, dialogismo, voz, análise do discurso, discurso, linguagem, gêneros do discurso, sem a delimitação de um período específico, ou seja, foram selecionados artigos publicados até abril de 2019. Após a seleção por meio desses descritores, realizamos uma leitura prévia dos trabalhos, de forma a filtrar quais realmente fariam parte do escopo que estávamos buscando. Por exemplo, no descritor linguagem foi possível encontrar trabalhos que não tinham nenhuma relação com Bakhtin, portanto, não poderiam fazer parte do corpus. Assim, nesta busca, procuramos por artigos que fossem da área de Educação em Ciências e que tivessem em seu corpo elementos do pensamento bakhtiniano. Obviamente, pode ter acontecido de algum trabalho publicado nessas revistas atender aos critérios de seleção, mas não fazer parte do corpus se o sistema de busca da revista não localizou a partir dos descritores utilizados ou, até mesmo, se os descritores não foram suficientes para isso. Entretanto, acreditamos que os descritores utilizados para as buscas são pertinentes e permitem um levantamento bastante aproximado da totalidade da produção. Os quantitativos referentes aos artigos que compõem o nosso corpus serão apresentados na seção seguinte, por ora destacamos apenas que nem todas as revistas apresentaram artigos que atendessem ao nosso critério de seleção.

Após a delimitação do corpus, foi realizada a leitura detalhada dos artigos, identificando elementos estruturantes, como objetivos de pesquisa, obras do Círculo bakhtiniano utilizadas, conceitos, referenciais teórico-metodológicos, sujeitos de pesquisa, questões metodológicas, temática do trabalho, entre outros. A partir dessa leitura foi possível buscar regularidades, aproximações e distanciamentos, identificar

2 Talvez não seja ideal falar em apropriação em função de não ser um estudo exaustivo, por isso, cientes dessa limitação, referimo-nos a uma reflexão de possíveis apropriações reveladas a partir da leitura desses textos específicos, de forma a elaborar um sentido para os diferentes usos e interpretações de conceitos e ideias por esse conjunto de textos. 
tendências, lacunas e apontamentos e realizar sistematizações. É comum neste tipo de pesquisa a delimitação de categorias de análise, entretanto, tais categorias não podem ser definidas a priori pois entendemos que emergem a partir dos dados e vão se modificando no decorrer da pesquisa. Assim, partimos do que consideramos elementos estruturantes do artigo, por meio dos quais foi possível estruturar e sistematizar alguns achados e, a partir desses, desenvolver uma análise que questionasse, problematizasse e levasse a uma compreensão do que estava emergindo. Entendemos que esses achados são fruto da correlação entre textos, aquilo Bakhtin (1997, p. 405) chama de cotejamento, que significa que "toda palavra (todo signo) de um texto conduz para fora dos limites desse texto. A compreensão é o cotejo de um texto com os outros textos". Ou seja, os artigos que constituem o nosso corpus, como textos que são, se correlacionam, de forma a gerar tensão entre si e, portanto, disputar, se contrapor ou concordar para, assim, produzir sentido. Assim, os sentidos construídos da relação entre os textos do corpus serão ainda colocados em interação com textos do Círculo bakhtiniano e de comentadores desse grupo, de maneira a produzir uma compreensão dos sentidos emergentes.

Destacamos que, ao trazer as ideias do Círculo para desenvolver análises que nos ajudem a compreender a incorporação desse referencial pela área de Educação em Ciências, não queremos colocar nossa compreensão acerca de suas ideias como correta, superior ou única com relação ao que entendemos como superficial ou equivocado nesses trabalhos, uma vez que propor que haja apenas uma leitura "correta" dos textos do Círculo seria antibakhtiniano (Faraco, 2001). Como nos ensina Bubnova (2010), é importante deixar de lado o adjetivo correto e pensar em uma interpretação mais ou menos estável das ideias do círculo. Assim, nossas análises se pautarão pelas interpretações das ideias do círculo que consideramos mais estáveis, estabilização esta dada pela nossa leitura da obra do Círculo com o aporte de grandes estudiosos como Augusto Ponzio, Beth Brait, Carlos Alberto Faraco, João Wanderley Geraldi, Susan Petrilli e Tatiana Bubnova. Por fim, destacamos que não identificaremos no nosso trabalho os autores dos artigos analisados, pois não é nosso objetivo apontar quem são os autores que possuem uma compreensão mais próxima à estabilizada ou não. Nosso objetivo é contribuir para os estudos bakhtinianos na área, sempre com respeito ao outro, pois assumimos que ser indiferente ao outro não é bakhtiniano e seria, portanto, incoerente. Isso não significa que não apontaremos possíveis fragilidades nos trabalhos, pois Bakhtin nos ensina que é necessário tensionar e provocar respostas no outro, que o conhecimento está sempre em construção e mutação. Assim, concebemos que visões diferentes precisam ser apresentadas e tensionadas, sem que isso deprecie o que foi produzido pelo outro, mas para que, em um movimento alteritário, essas visões diferentes produzam um novo "outro" que possa responder ativamente às nossas provocações e, consequentemente, produzir um novo "eu".

\section{Levantamento da produção}

A partir da busca realizada, conforme descrito na seção anterior, localizamos 
um quantitativo de 70 artigos $^{3}$. Se considerarmos que nossa busca não se limitou a um período específico, poderíamos dizer que se trata de um número bastante reduzido de artigos. Por outro lado, a aproximação do referencial à área de Educação em Ciências é uma construção que se inicia há uns 20 anos de forma muito tímida e, mais recentemente, nos últimos dez anos, começa a ganhar um pouco mais de força. Como é possível perceber no gráfico da Figura 1, os primeiros artigos que encontramos nesses periódicos datam o ano de 2001. É possível verificar que, entre 2001 e 2009, a produção de trabalhos na área que trazem o pensamento bakhtiniano são bastante reduzidas e apresentam algumas variações, de forma que em alguns anos há uma produção máxima de três (2006 e 2009) artigos e, em outros, nenhum artigo (2005 e 2007). Nos demais anos desse período há uma variação entre um e dois artigos por ano, constituindo uma média de pouco mais de um artigo por ano. Já na década seguinte, percebemos uma diferença nos quantitativos de produção: a partir de 2010 a produção começa a crescer e mantém-se em números maiores, com algumas oscilações. Percebe-se grandes saltos nos anos de 2011, 2013 e 2015 com a produção de um máximo de oito artigos, já o menor número de artigos produzidos nesta década é verificado no ano de $2014^{4}$ com três artigos, o valor máximo apresentado em alguns anos do período anterior. Na década 2010-2019 há uma média de cinco artigos por ano, um número quatro vezes maior que no período 2001-2009, atentando ainda para o fato de que no momento da elaboração do presente trabalho o ano de 2019 estava no início. Assim, olhando para a evolução da produção, percebemos que o pensamento bakhtiniano vem sendo utilizado com mais frequência pela área de Educação em Ciências na última década.

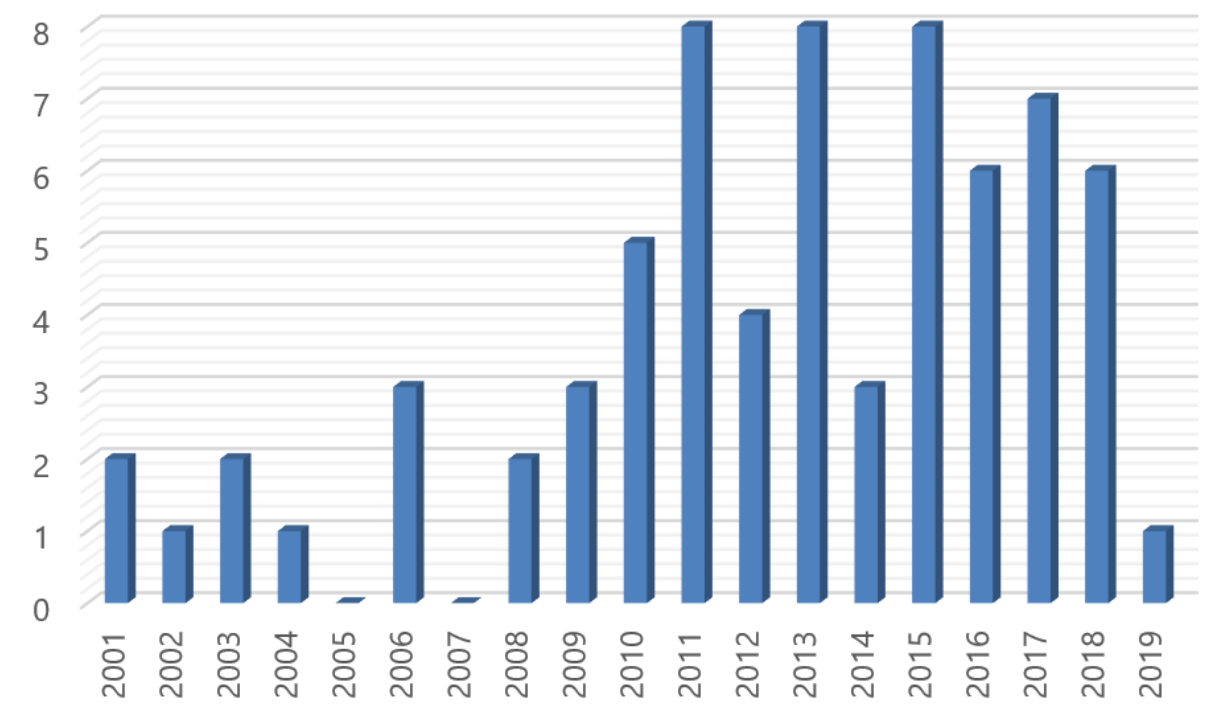

Figura 1. Evolução da produção

3 Ao final do artigo apresentamos a listagem dos artigos estudados.

4 Não consideramos o ano de 2019 como o menor ano de produção da década 2010-2019, pois apenas o primeiro quadrimestre deste ano faz parte da presente pesquisa. 
Por outro lado, percebemos que trabalhos com o pensamento bakhtiniano são publicados mais em algumas revistas do que em outras. Por exemplo, a RBEF, a mais antiga da área, com publicações desde 1979, não publicou nenhum artigo alinhado ao objetivo da nossa revisão. Já outras revistas mais recentes, como a Ensaio (início das publicações em 1999) e RBPEC (início das publicações em 2001), somam juntas 50\% da produção relacionada ao pensamento bakhtiniano da área. As publicações por revista são as seguintes: 1) RBPEC - 26\%; 2) Ensaio - 24\%; 3) C\&E - 19\%; 4) IENCI - 17\%; 5) $\mathrm{CBEF}-6 \%$; 6) Práxis - 4\%; 7) Alexandria - 3\%; 8) Areté - 1\%. Não localizamos artigos que se enquadrassem em nosso escopo nas revistas AM, RBECT e, como já mencionamos, na RBEF.

Quanto às instituições que mais publicaram trabalhos relacionados ao pensamento bakhtiniano na área, apontamos a predominância de quatro instituições. Para cada artigo do nosso corpus identificamos quais instituições estavam vinculadas a cada um dos trabalhos, contabilizando apenas uma vez caso houvesse mais de um autor da mesma instituição, pois nosso objetivo é conhecer em quantos artigos cada instituição está presente. Além disso, contabilizamos a instituição a que o autor pertencia no momento da publicação, assim, em alguns momentos um autor pode estar vinculado a uma determinada instituição e, em outros momentos, a outra. No total inventariamos 33 instituições vinculadas aos trabalhos, mas percebemos que as instituições mais presentes nessas produções são: UFMG, presente em 22 dos 70 trabalhos, portanto, presente em pouco mais de 31\% dos trabalhos; UFRJ, presente em 14 dos 70 trabalhos, portanto, em 20\%; UFRGS, presente em 12 dos 70 trabalhos, portanto, pouco mais de 17\%; e USP, presente em dez dos 70 trabalhos, portanto, presente em pouco mais de $14 \%$ dos trabalhos. As demais instituições tiveram participação em quatro trabalhos ou menos.

Acompanhando esses dados, percebemos que os pesquisadores com maior produção de trabalhos envolvendo o pensamento bakhtiniano são dessas instituições: três da UFMG, dois da UFRGS e um da UFRJ/UFRGS. A pesquisadora que possui a maior quantidade de trabalhos que abordam o pensamento bakhtiniano na área é a professora Fernanda Ostermann, da UFRGS, com um total de 11 artigos publicados. Em segundo lugar, aparece a professora Flávia Rezende da UFRJ até o ano de 2015 e, agora, apenas vinculada à UFRGS, com dez trabalhos. Na sequência há três pesquisadores com produção equivalente a sete artigos: professor Cláudio José de Holanda Cavalcanti, da UFRGS; professora Maria Emilia Caixêta de Castro Lima, da UFMG; e o professor Orlando Gomes de Aguiar Junior, também da UFMG. Por fim, o professor Eduardo Fleury Mortimer da UFMG é outro pesquisador com maior produção de trabalhos que abordam o pensamento bakhtiniano, com seis trabalhos publicados. Destacamos que inventariamos um total de 104 autores de trabalhos, sendo que depois dos seis com maior produção, os demais autores possuem no máximo três artigos publicados. Destacamos mais uma vez que nosso corpus limita-se aos periódicos nacionais citados e localizados a partir dos nossos descritores. Sobre os principais autores, a Figura 2 traz 
algumas informações importantes.

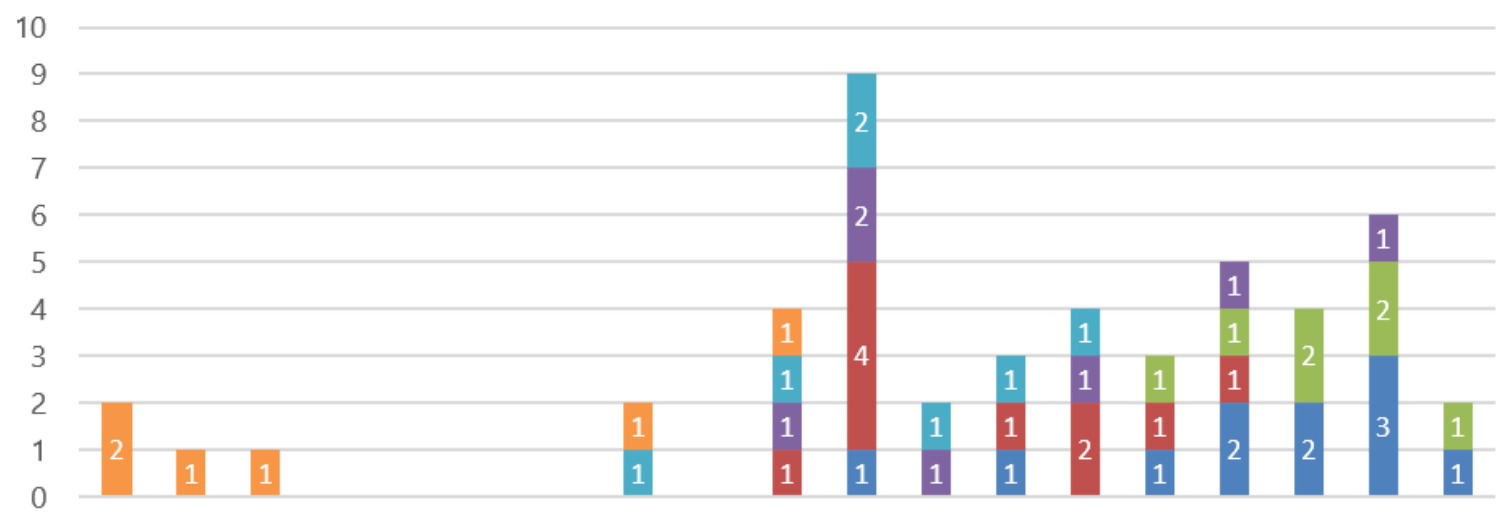

2001200220032004200520062007200820092010201120122013201420152016201720182019

Ostermann $\quad$ Rezende $\quad$ Cavalcanti $\quad$ Lima $\quad$ Aguiar Jr. $\quad$ Mortimer

Figura 2. Produção dos principais autores no decorrer do tempo

Pelo gráfico apresentado na Figura 2, percebemos que os primeiros trabalhos com o pensamento bakhtiniano publicados na área são de autoria do professor Eduardo Mortimer que, como um dos principais autores, destaca-se com produções até o ano de 2010. Entre os anos de 2011 e 2015, vemos uma produção grande da professora Flávia Rezende, com 10 artigos nesse quinquênio e, em um período mais recente - a partir de 2016, percebemos a produção mais intensa dos professores Fernanda Ostermann e Cláudio Cavalcanti. Os professores Orlando Aguiar Junior e Maria Emilia Caixêta Lima, tiveram uma produção mais perene ao longo dos anos, respectivamente, de 2008 e 2014 (sete trabalhos em sete anos), e de 2010 a 2018 (sete trabalhos em oito anos). O ponto mais relevante que gostaríamos de destacar destes dados diz respeito ao surgimento do pensamento bakhtiniano na área, pois entendemos que as condições em que este se dá são cruciais para compreender os movimentos que foram estabelecendo a apropriação das ideias do Círculo bakhtiniano pela área. Neste aspecto, pelos dados que temos, fica claro que o pioneirismo nos estudos bakhtinianos na nossa área é creditado ao professor Eduardo Mortimer, a partir do qual, portanto, é possível fazer a contextualização da chegada do pensamento bakhtiniano na área. Assim, cabe questionar: Quem é este sujeito? De que lugar fala? Por que traz Bakhtin para a área? Quais foram suas influências? Uma rápida consulta ao currículo Lattes nos aponta que se trata de um professor e pesquisador que, já na sua pesquisa de doutoramento, estava dedicado ao estudo sobre dinâmicas discursivas em sala de aula, interesse que mantém ao longo de sua carreira, como ele próprio afirma: "Entre meus interesses de pesquisa destaco: a relação entre elaboração de conceitos científicos e o uso da linguagem em salas de aula de química e ciências". Nitidamente, o enriquecimento de sua formação durante parte de seu Doutorado na Universidade de Leeds parece ser um elemento crucial, pois lá teve contato com ideias de Vygotsky e Bakhtin. Fez parcerias, por exemplo, com Philip Scott, 
membro do Grupo de pesquisa de sua orientadora de Doutorado sanduíche, Rosalind Driver, reconhecido por trabalhar com a teoria sociocultural na análise do discurso em sala de aula. Além disso, consta em seu Lattes que trabalhou e publicou trabalhos com James Wertsch, psicólogo norte-americano, considerado uma referência nos estudos de Vygotsky e Bakhtin. Certamente essas foram grandes influências do pesquisador que trouxe o pensamento bakhtiniano para a área. Entendemos que isso impactou de duas formas a apropriação do referencial bakhtiniano. Primeiramente, como pioneiro, Eduardo Mortimer é um autor bastante citado nos artigos do nosso estudo, de forma que em pelo menos 21 (desconsiderando os de sua própria autoria) dos 70 artigos há referência a algum trabalho dele que envolve o pensamento bakhtiniano. Portanto, muito do que se produziu na área sobre esta temática tem vínculos diretos com as ideias do Círculo expostas no início de sua aproximação à área de Educação em Ciências e que, provavelmente, são alinhadas às concepções de Scott e Wertsch. Em segundo lugar, talvez por essa proximidade entre Mortimer e Wertsch, o psicólogo norte-americano é o autor que mais é referenciado nos trabalhos para compreender aspectos do pensamento bakhtiniano na área de Educação em Ciências do Brasil.

\section{Caracterizando os artigos}

Os artigos do nosso estudo são relacionados em proporções diferentes a quatro áreas: em sua maioria pertencentes à área da Física (37\%), seguido da área que denominamos Ciências (33\%) - quando há uma abordagem mais geral que pode congregar tanto a Física, quanto a Química e a Biologia, seguido da Química (21\%) e da Biologia (9\%). Desses trabalhos, quanto à natureza da pesquisa, apontamos que 10 apresentam o que denominamos por reflexões teóricas, uma vez que não possuem base empírica de sustentação às proposições ou a empiria utilizada serve para exemplificar determinada proposição teórica (exemplo o artigo 37). Dois trabalhos são de revisões (artigos 68 e 69), nos quais se verifica um mapeamento acerca da comunicação científica na Educação em Ciências e um trabalho de desenvolvimento (artigo 65), no qual são apresentadas atividades didáticas relacionadas à FMC. Por fim, a maioria dos trabalhos (55), é de natureza empírica, isto é, as proposições desenvolvidas se pautam pela empiria; nesses trabalhos constitui o material empírico produtos educacionais, documentos oficiais, documentos norteadores de curso, revistas de divulgação científica, livros didáticos, obra de ficção científica, textos escritos por alunos, enunciados escritos em resposta a questionários, enunciados falados em situação de entrevistas semiestruturadas, enunciados de professores, enunciados de alunos, enunciados de interações discursivas entre professores e alunos. Ademais, há uma pluralidade de sujeitos envolvidos nessas pesquisas: são estudantes de escolas públicas e privadas, da educação básica, educação de jovens e adultos e educação superior - licenciaturas e bacharelados em Física, Química e Biologia, professores-alunos de cursos de especialização e mestrados profissionais, tradutor de libras, palestrantes, professores.

De forma a organizar toda esta produção, no sentido de mostrar o que tem sido 
pesquisado, organizamos os trabalhos em linhas temáticas inspiradas no maior evento nacional da área, o Encontro Nacional de Pesquisa em Educação em Ciências (ENPEC). Destacamos que esta organização é bastante delicada, uma vez que, em muitos casos, os trabalhos se aproximam a mais de uma linha temática. Assim, diante desse aspecto tênue que envolve tal organização, procuramos associar os trabalhos à linha temática que nos parecia mais característica de cada um deles, o que nos levou à distribuição ${ }^{5}$ dos trabalhos de acordo com as porcentagens expostas na Figura 3. Percebe-se que o pensamento bakhtiniano povoa uma diversidade de linhas temáticas na área, sendo mais característico de trabalhos que tratam da formação docente, de linguagens e discurso, de processos, recursos e materiais didáticos, educação em espaços não-formais e divulgação científica e educação e aprendizagem de conceitos e processos científicos.

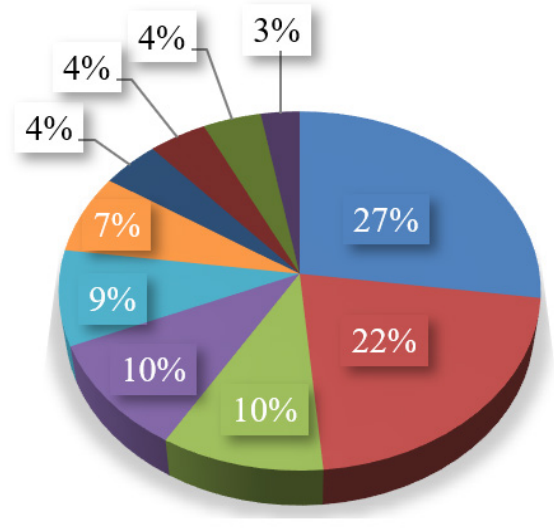
- Formação de professores
- Linguagens e discurso
- Processos, recursos e materiais educativos
- Educação em espaços não-formais e divulgação científica
- Educação e aprendizagem de conceitos e processos científicos
- Diversidade, multiculturalismo e interculturalidade
- Currículos
- Alfabetização científica e tecnológica, abordagens CTS/CTSA
- Políticas educacionais
- Questões teóricas e metodológicas da pesquisa

Figura 3. Linhas temáticas

Os trabalhos da linha "Formação de professores" têm como preocupação investigar, por exemplo, a apropriação discursiva docente sobre documentos oficiais e modelos formativos, a atribuição de sentidos por professores à qualidade na educação, ao ensino por investigação e às TIC's, memoriais docentes e currículos formativos, temas relacionados à Física Moderna e Contemporânea (FMC) na formação docente, a construção discursiva da identidade docente, bem como compreensões docentes acerca da abordagem CTS e da História da Ciência (HC). Já os trabalhos associados à linha temática "Linguagens e discurso" debruçam-se essencialmente sobre questões como a argumentação em sala de aula, estudo dos gêneros do discurso da sala de aula e do livro didático, leitura, escrita e perguntas em sala de aula, aspectos não-verbais e intersubjetividade na sala de aula, interações discursivas, bem como a construção do conhecimento científico por meio do

5 Relação dos trabalhos de cada linha: Formação de professores $(2,3,4,5,9,12,16,20,21,22,26,29,35,48$, 51, 53, 54, 59, 61); Linguagens e discurso (19, 23, 28, 30, 31, 33, 34, 37, 42, 43, 44, 45, 49, 50, 52); Processos, recursos e materiais didáticos $(25,47,57,62,63,64,65)$; Educação em espaços não-formais e divulgação científica $(14,27,38,55,66,68,69)$; Educação e aprendizagem de conceitos e processos científicos $(6,8,13,15,36,46)$; Diversidade, multiculturalismo e interculturalidade (11, 17, 32, 40, 56); Currículos (1, 7, 39); Alfabetização científica e tecnológica, abordagens CTS/CTSA (18, 41, 67); Políticas Educacionais $(58,60,70)$; Questões teóricas e metodológicas da pesquisa $(10,24)$. 
discurso. Nos trabalhos associados à temática "Processos, recursos e materiais educativos" percebemos o propósito de analisar livros didáticos com relação a questões envolvendo a HC e à FMC. Também verificamos análises com relação a recursos auxiliares ao processo de ensino e aprendizagem, como o caderno e o laboratório didático e, ainda, um trabalho destinado a apresentar atividades didáticas relacionadas à FMC. A linha temática "Educação em espaços não-formais e divulgação científica" caracteriza trabalhos que buscam, essencialmente, estudar questões relacionadas à divulgação científica, seja com relação à sala de aula, a revistas de divulgação científica ou à transposição do discurso científico para o de divulgação. Por fim, os trabalhos associados à temática "Educação e aprendizagem de conceitos e processos científicos" buscaram, por exemplo, discutir ou estudar a formação dos conceitos científicos em sala de aula, analisar uso de conceitos e a elaboração conceitual de estudantes. São exemplos que nos mostram a diversidade de tópicos abordados sob a ótica do Círculo na área de Educação em Ciências. Diante disso, buscaremos na próxima seção trazer elementos que auxiliem na compreensão de como se constitui o pensamento bakhtiniano nesses trabalhos.

\section{0 pensamento bakhtiniano nos trabalhos}

Apontamos inicialmente que as ideias do Círculo bakhtiniano são discutidas nos trabalhos sem grandes variações, isto é, a área parece comungar de um conjunto de conceitos desse pensamento que se repete nos trabalhos. Pelas leituras das produções fica clara a predileção da área por determinados conceitos como: enunciado, suas características e peculiaridades; voz; dialogismo; gêneros do discurso; compreensão ativa/responsiva; contexto extraverbal; signo, significação e tema; discurso alheio. Há, obviamente, produções que se aventuram por outros conceitos, mas, em geral, percebemos que estes são os conceitos que embasam a produção da área de forma mais constante. Esses dados nos dão indicativos da pequena porção de escritos do Círculo apropriada pela área, o que nos instigou a realizar um estudo das obras presentes nos trabalhos. Assim, buscamos nas referências dos artigos as obras do Círculo citadas e as localizamos no corpo do texto para compreender a que elementos daquela dada obra o trabalho se referia, pois uma análise simplesmente quantitativa do que é apontado nas referências não nos daria elementos esclarecedores da relação conceito-obra. Quantitativamente percebemos que as obras mais citadas pelos artigos são "Marxismo e filosofia da linguagem" (MFL), referenciada em quase $80 \%$ dos artigos e "Estética da criação verbal" (ECV) ou algum texto constituinte desta coletânea, referenciados em quase $85 \%$ dos trabalhos. Sobre as citações, destacamos que, em alguns momentos, ocorre de alguma obra ser citada apenas nas referências, mas não constar no corpo do texto e, em outros, há citações de algumas obras no corpo do texto que não constam nas referências. Há ainda citações inseridas no texto apenas com o propósito de evocar algum escrito do Círculo, sem desenvolvimento de teor temático dele. Ao relacionar as referências apresentadas nos trabalhos com as citações presentes no corpo do texto, percebemos, ainda, que os olhares da área para essas obras costumam ser bastante 
restritos a algumas partes específicas, como a Parte II de MFL e ao texto "Os gêneros do discurso" de ECV. Por exemplo, nosso levantamento aponta que 90\% das citações a ECV se referem, essencialmente, ao texto "Os gêneros do discurso", embora citem a obra toda. Esses dados nos apontam que a área de Educação em Ciências ainda está muito restrita ${ }^{6}$ à primeira obra do Círculo publicada no Brasil (MFL), em 1979, e a apenas uma parte de uma rica coletânea que apresenta muitos conceitos da arquitetônica de Bakhtin. Sobre o primeiro, cabe destacar que é uma tradução da tradução, ou seja, sua tradução para o português se deu a partir da versão francesa e, portanto, é influenciada por essas lentes, caracterizadas por uma tendência de tentar encaixar as ideias do Círculo à atmosfera intelectual francesa da época da tradução (Bezerra, 2013). Neste sentido, entende-se a crítica feita por Faraco (2001), por exemplo, às tentativas de rotular Bakhtin de acordo com determinadas tendências que, claramente, se mostram sem sucesso e acabam contribuindo para uma apropriação caótica do pensamento bakhtiniano. Diante disso, apontamos que esses dados nos indicam a íntima relação entre os conceitos bakhtinianos mais presentes na área e as obras do Círculo que embasam essas produções.

Ademais, percebemos que muitas vezes o quadro teórico bakhtiniano é interpretado com o aporte de estudiosos da obra do Círculo e, neste sentido, destacamos como autor mais frequentemente utilizado para compreender as ideias do Círculo na Educação em Ciências o psicólogo norte-americano, James Wertsch. Ressaltamos mais uma vez que acreditamos que essa proximidade da Educação em Ciências com Wertsch tenha relação com o início das produções na área. De toda forma, destacamos ainda que, mesmo em uma proporção menor, a autora brasileira mais utilizada para ancorar a compreensão de conceitos bakhtinianos nos trabalhos da área é a professora Beth Brait, respeitada estudiosa do Círculo bakhtiniano.

Outra característica do pensamento bakhtiniano na área é sua abordagem concomitante a uma diversidade de referenciais. Sem esgotar essa questão, apontamos a presença de referenciais de formação docente - a título de exemplo, Tardiff, Porlán, Giroux e Contreras, referenciais ligados à questão de gênero, referenciais sobre argumentação, referenciais associados a questões sociocientíficas, referenciais das teorias de currículo, da sociologia, da psicologia (essencialmente Vygotsky) e da linguística, dentro da qual, destacamos a análise do discurso de linha francesa (ADF). Na maioria das vezes tais referenciais são utilizados sem muita articulação ao pensamento bakhtiniano, entretanto, destacamos a auspiciosa inciativa de alguns trabalhos em desenvolver a aproximação entre os referenciais e as ideias do Círculo. Assim, destacamos que na área de Educação em Ciências se verifica o desenvolvimento de aproximação entre o pensamento bakhtiniano e de Bourdieu e de Latour. Nos trabalhos 29 e 41 percebemos o

6 Obviamente houve citações a outras obras, entretanto, em uma quantidade pouco significativa. Assim, mencionamos que tiveram pelo menos uma citação as seguintes obras relacionadas ao Círculo, ordenadas de acordo com a maior frequência: The dialogic imagination; O discurso no romance (Questões de literatura e estética); Speech genres and other late essay; Discurso na vida, discurso na arte; Estrutura do enunciado; Problemas da poética de Dostoievski; Para uma filosofia do ato responsável; Método formal nos estudos literários; Cultura popular na Idade Média: o contexto de François Rabelais. 
desenvolvimento de uma primorosa aproximação entre as ideias de Pierre Bourdieu e Bakhtin, nos quais

são destacados três pontos principais que aproximam essas teorias: o posicionamento contrário à visão de linguagem como um sistema abstrato e arbitrário, em que é possível visualizar a relação entre as noções de linguagem e capital social; a concepção de que o indivíduo se constitui do social para o individual, no qual parece emergir uma relação entre os conceitos de ideologia e habitus; e, por fim, a atribuição de sentido ao discurso que requer conhecer a posição que o indivíduo ocupa na esfera ou campo em que atua, no qual os conceitos de contexto extraverbal e campo se relacionam. Já o trabalho 57 aproxima o pensamento bakhtiniano das ideias de Bruno Latour, a partir dos conceitos de atores, performances e tradução da sociologia simétrica de Latour com signo e dialogia do Círculo.

Por fim, um aspecto que pode ser significativo com relação à forma como as ideias do Círculo bakhtiniano são recebidas pela área é a maneira de denominá-las em relação ao todo da obra nos trabalhos. Diante disso, encontramos uma multiplicidade de formas de nominação do pensamento bakhtiniano, tais como: Teorias de Bakhtin, Estudos de Mikhail Bakhtin, Teoria da enunciação de Bakhtin, Teoria das enunciações de Bakhtin e seu círculo, Concepções de Bakhtin, Proposições de Bakhtin, Teoria dialógica de Bakhtin, Teoria da linguagem e do dialogismo de Bakhtin, Filosofia da linguagem de Bakhtin, Teoria das vozes de Bakhtin, Metalinguística de Bakhtin, Filosofia translinguística de Bakhtin, Análise do discurso proposta por Bakhtin.

$\mathrm{O}$ primeiro elemento que chama atenção nessas formas de referência às ideias desenvolvidas no conjunto das obras do Círculo é exatamente a margem que dão para a possibilidade de descaracterização de um trabalho feito a muitas mãos, o trabalho do Círculo (mesmo que esse nunca tenha existido de forma institucionalizada), com a priorização da figura de Bakhtin com relação aos demais membros desse grupo de intelectuais, nitidamente marcada pela expressão "de Bakhtin". O movimento que levou Bakhtin a ser uma figura mítica certamente perpassa a questão da autoria das obras, aquilo que tem se denominado problema dos textos disputados. Como aponta Seriot (2015), alguns anos após a redescoberta de Bakhtin, publicações seminais atribuíram a ele a autoria de obras assinadas por Voloshinov e Medvedev, bem como sugeriram serem estes últimos alunos, colaboradores e/ou discípulos do primeiro, colocando, assim, Bakhtin como o grande mestre, líder, orientador. Na verdade, os membros, de origens multidisciplinares, desse grupo bastante heterogêneo, pertenciam também a outros agrupamentos, tinham autonomia intelectual e se influenciavam reciprocamente, não cabendo conceder a Bakhtin o papel de grande liderança intelectual. Supõe-se, razoavelmente, que o "Círculo de Bakhtin" nunca existiu, isto é, o grupo nunca se autodenominou assim, sendo esta uma invenção posterior e apócrifa, proposta por Leontiev (Seriot, 2015).

Ponzio (2011 citado em Geraldi, 2013) ajuda a entender por que o Círculo de Bakhtin nunca existiu: nunca existiu se considerado na acepção de "escola" no sentido 
acadêmico do termo, muito menos existiu se a este for atribuído a expressão "de Bakhtin" no sentido de pertencimento, de derivação. Parece estável a ideia de que o Círculo não era de Bakhtin, não era liderado por ele, "trata-se mais de um grupo, de uma intensa e afinada colaboração, em clima de amizade, em pesquisas comuns, a partir de interesses e competências diferentes" (Ponzio, 2011 citado em Geraldi, 2013, p. 10). Assim, nos parece razoável que aquilo que chamamos de pensamento bakhtiniano constitui um corpus de fundamentos provenientes da constante interlocução entre intelectuais desse grupo (principalmente, mas não apenas, o filósofo Bakhtin, o estudioso da literatura Medvedev e o estudioso da linguagem Voloshinov), de forma que "o que caracteriza como 'bakhtinianos' são os temas, os interesses, as perguntas, o modo de busca de respostas em diálogo constante entre os membros do grupo. É neste sentido que se deve entender o 'Círculo de Bakhtin”' (Geraldi, 2013, p. 11).

Outra questão que chama atenção nessas formas de se referenciar ao pensamento bakhtiniano na área de Educação em Ciências é a ênfase em determinadas construções teóricas produzidas pelo círculo, como nos nomes de referência "Filosofia da linguagem" (certamente relacionado às proposições de MFL) ou "Teoria da enunciação" (também relacionado a MFL, além de outros ensaios dos anos 20). Ênfases que entendemos estarem relacionadas à predominância conceitual verificada e às obras mais apropriadas pela área. Em outras formas de nominação, percebemos a ênfase no objeto principal da ciência da linguagem proposta pelo círculo, o dialogismo. Há ainda, aquelas que apontam para algo que talvez o círculo nunca tenha proposto, como uma "Teoria das vozes" e uma "Análise do discurso" 7 . Já outras, parecem carregadas de certa redundância, como "Filosofia translinguística de Bakhtin", inclusive, trazendo um termo nunca proposto pelo círculo: translinguística.

Sem propor que há uma denominação correta para este pensamento considerado inclassificável, entendemos ser importante considerar que as ideias do Círculo bakhtiniano estão envolvidas no que será denominado por Bakhtin, conforme os escritos de sua última fase, de Metalinguística. Bakhtin (2013), ao propor a Metalinguística, uma nova ciência da linguagem que iria além da Linguística - na qual o caráter dialógico da língua é negligenciado, sistematiza e aprofunda as ideias desenvolvidas pelo Círculo desde os anos 20. Entretanto, como aponta Souza (2002), o termo que prevaleceu para identificar a obra de Bakhtin foi o dialogismo e não a Metalinguística, ou seja, o objeto desta última acaba falando mais alto que a ciência da qual ele é constitutivo. Ponzio (2010), que considera que essa ciência da linguagem proposta por Bakhtin poderia também ser chamada de filosofia da linguagem ${ }^{8}$, destaca seu aspecto crítico:

Valorizada em termos de "crítica", não só em sentido literário, mas também filosófico, a partir de Kant e de Marx, a contribuição fundamental de sua filosofia da linguagem ou metalinguística - como ele mesmo nomeia sua abordagem do signo, da enunciação, do

7 Discutimos esta polêmica questão adiante no nosso texto.

8 Em Souza (2002), que estuda a construção da Metalinguística, não se percebe essa proposição de que a Metalinguística também poderia ser chamada de Filosofia da linguagem, entretanto, a estreita relação entre elas fica evidente: para ele não há dúvidas que é em uma filosofia marxista da linguagem que a metalinguística deita suas raízes. 
texto, dos gêneros do discurso, das relações entre a escritura literária e expressões não verbais da cultura popular - consiste em ter inaugurado uma crítica da razão dialógica (Ponzio, 2010, p. 296, grifos do autor).

Entretanto, este caráter crítico da Metalinguística foi prejudicado em decorrência de algumas distorções na compreensão do pensamento bakhtiniano, como os malentendidos a respeito do diálogo e dialogismo, bem como a mudança do termo metalinguística por translinguística (Ponzio, 2010). Tais distorções, infelizmente, como aponta Ponzio (2010), são identificadas nas produções daqueles que tiveram o mérito de ter contribuído para a difusão das ideias do Círculo, como, a título de exemplo, Torodov, Krysinski, Wellek e Clark e Holquist. Sem entrar no mérito das distorções provocadas, destacamos que substituições em alguns termos encontrados nas obras do Círculo figuram como desencadeadores desses processos, são eles: intertextualidade no lugar de dialogismo (dialógico passa a ser utilizado para alguns casos específicos de intertextualidade, como a troca de turno entre interlocutores) e translinguística no lugar de metalinguística. Essas substituições, propostas inicialmente por Kristeva e disseminadas por Torodov, por exemplo, foram realizadas pelo entendimento de serem consideradas mais apropriadas e livrarem de um possível embaraço que poderiam causar na tradução para o francês (Souza, 2002) ou, sob outra perspectiva, como aponta Bezerra (2013), foram propostas com a tentativa encaixar o pensamento bakhtiniano em uma perspectiva estruturalista (a ideia de encaixar o pensamento bakhtiniano à atmosfera intelectual francesa). $\mathrm{O}$ fato é que o termo translinguística (ainda assim, ressaltamos, considerado por muitos como mais adequado) nunca foi proposto nos escritos do Círculo e sua utilização no lugar do termo metalinguística tem a finalidade de reduzir o pensamento a mais uma corrente linguística (Bezerra, 2013) e eliminar seu caráter crítico, além de introduzir uma divisão de competências: a linguística ocupa-se da língua e a translinguística do discurso (Ponzio, 2010).

A translinguística ocupa-se do discurso, enquanto a linguística continua a ocupar-se da língua sem interessar-se pelo seu constitutivo caráter dialógico, ou melhor, ignorando-o: dialógico, mas, para Torodov, no sentido de "intertextualidade" é somente o discurso, do qual, justamente, ocupa-se a translinguística e não a linguística. (...) [Porém] Bakhtin acredita que a dialogicidade pode ser encontrada também nas relações puramente formais ou linguísticas em sentido estrito, como também nas relações estilísticas e retóricas (a repetição anafórica, a tradução, a metáfora) no qual se encontram e se fundem "vozes" pertencentes a campos discursivos e a níveis linguísticos diferentes. (...). O enunciado é uma inferência mais ou menos explícita e, como tal, é dialógica, nessa são ouvidas, pelo menos, duas vozes. Torodov não compreende isso adequadamente quando considera que as relações lógicas, como as relações puramente formais ou linguísticas em sentido estrito (de anaphora, paralelismo etc.), são excluídas da dialogicidade (Petrilli, 2012, p. 108-109).

Fica claro que "a dialógica bakhtiniana refere-se não apenas ao discurso, o objeto da translinguística de Torodov, mas também à consciência, ao inconsciente, 
ao pensamento, à ideologia, à linguagem, à língua, ao corpo, ao signo verbal e nãoverbal" (Ponzio, 2010, p. 320, grifos do autor). Diante dessas distorções que envolvem o termo translinguística, acompanhamos Ponzio (2010), Petrilli (2012), Bezerra (2013), Brait (2006) e Souza (2002) e chamamos essa nova ciência da linguagem proposta por Bakhtin de Metalinguística. Tal ciência tem caráter filosófico, atravessa campos disciplinares, situando-se em um ponto de intersecção ou, como aponta Souza (2002, p. 131), "na fronteira de uma filosofia da palavra, de onde provém sua orientação filosófica; da linguística, em relação a qual se coloca como um estudo complementar [mas não excludente] e autônomo; e da estilística”.

Intitulamos este capítulo "O discurso em Dostoiévski” porque temos em vista o discurso, ou seja, a língua em sua integridade concreta e viva e não a língua como objeto específico da linguística, obtido por meio de uma abstração absolutamente legítima e necessária de alguns aspectos da vida concreta do discurso. Mas são justamente esses aspectos, abstraídos pela linguística, os que têm importância primordial para os nossos fins. Por este motivo as nossas análises subsequentes não são linguísticas no sentido rigoroso do termo. Podem ser situadas na metalinguística, subentendendo-a como um estudo - ainda não constituído em disciplinas particulares definidas - daqueles aspectos da vida do discurso que ultrapassam - de modo absolutamente legítimo - os limites da linguística. As pesquisas metalinguísticas, evidentemente, não podem ignorar a linguística e devem aplicar os seus resultados. A linguística e a metalinguística estudam um mesmo fenômeno concreto, muito complexo e multifacetação - o discurso, mas estudam sob diferentes aspectos e diferentes ângulos de visão. Devem completar-se mutuamente e não fundir-se. Na prática, os limites entre elas são violados com muita frequência (Bakhtin, 2013, p. 214).

Portanto, parece não haver uma divisão de competências entre a Linguística e a Metalinguística, ambas estudam o discurso, porém sob diferentes ângulos de visão, de forma que uma não exclui a outra. Bakhtin refina um pouco mais essa definição facilitando o entendimento da diferença entre essas perspectivas, revestindo o objeto de sua nova ciência de uma dimensão extralinguística: é neste sentido que afirma que "as relações dialógicas (inclusive as relações dialógicas do falante com sua própria fala) são objetos da Metalinguística (Bakhtin, 2013, p. 215). Por outro lado, ao propor as relações dialógicas como objeto, Bakhtin não está propondo uma abordagem exclusivamente externa, interessa-lhe também a dialogicidade interna, marcada, por exemplo, pela bivocalidade. Assim, quanto ao objeto da Metalinguística, acrescenta Bakhtin (2013, p. 219):

O objeto principal do nosso exame, pode-se dizer, seu herói principal, é o discurso bivocal, que surge inevitavelmente sob as condições da comunicação dialógica, ou seja, nas condições da vida autêntica da palavra. A linguística desconhece esse discurso bivocal. Mas, achamos, é precisamente ela que deve tornar-se o objeto principal de estudo da metalinguística. 


\section{Uma análise das diferentes perspectivas presentes nos artigos sob o pensamento bakhtiniano}

A partir da leitura de cada um dos artigos buscamos correlacionar elementos basilares que nos ajudassem a construir uma compreensão sobre perspectivas de trabalho com o pensamento bakhtiniano. Inspirados no trabalho de Freitas (2004), estudamos a fundamentação teórica desses artigos, a metodologia empregada e as análises realizadas, de forma a compreender como esses três elementos se articulam no decorrer do trabalho e como estão implicados na busca por respostas a questões de pesquisa ou na argumentação de questões teóricas propostas, bem como na interpretação dos resultados obtidos. Assim como Freitas (2004), vamos utilizar, apesar das limitações já apresentadas, o termo apropriação para descrever essas diferentes perspectivas de trabalho com o pensamento bakhtiniano. Assim, estaremos fazendo uma reflexão a partir da nossa leitura desse conjunto de textos, com o propósito de elaborar sentidos para formas de conceber, interpretar, usar o pensamento bakhtiniano por certos grupos. Formas essas que jamais poderiam ser iguais e, por isso, representam diferentes apropriações do pensamento bakhtiniano. Vamos, na sequência, apresentar a leitura que fazemos dessas apropriações. Elementos que ajudam a compreendê-las melhor e exemplificá-las serão apresentados na seção seguinte.

Uma primeira reflexão para compreender como se dá a apropriação do pensamento bakhtiniano nos artigos é voltar os olhares para os conceitos que são empregados nos trabalhos e, com base nisso, foi possível perceber que 10\% dos trabalhos apresentam uma apropriação fortuita ${ }^{9}$ do pensamento bakhtiniano. Isto é, são trabalhos em que as ideias do Círculo pouco aparecem, de forma que não há o desenvolvimento coerente destas, mas apenas a delimitação de uma ou outra noção específica do autor. Assim, não parece possível compreender que são trabalhos fundamentados pela perspectiva do Círculo, uma vez que as noções apresentadas são de forma ocasional, passageira, aligeirada, sem grandes discussões e sem efetivas implicações para as análises desenvolvidas. É possível identificar uma segunda forma de apropriação do pensamento bakhtiniano, que se verifica em $20 \%$ dos trabalhos e será por nós denominada de restrita. Essa apropriação se caracteriza pela intencionalidade de desenvolver a fundamentação do trabalho com base no pensamento bakhtiniano de forma não-ocasional, entretanto, fica marcada pela superficialidade teórica. Entendemos que na fundamentação teórica de uma pesquisa são feitos recortes de elementos da dada teoria que são necessários para o desenvolvimento da investigação, pois seria impossível abordar, de forma adequada, a plenitude teórica característica. Apesar disso, nos parece claro que a complexidade da obra do Círculo bakhtiniano exige no mínimo uma contextualização, que implica, a nosso ver, a

9 Não citaremos trabalhos que são enquadrados nas apropriações para, como afirmamos no início do trabalho, não expor o nome dos autores. Ressaltamos mais uma vez que essas apropriações são uma construção elaborada a partir de um olhar para o todo do trabalho, de forma que exemplos que permitam compreender melhor suas características emergirão posteriormente, por meio de algumas reflexões desenvolvidas a partir de elementos identificados nos trabalhos. 
apresentação da visão de mundo que sustenta toda a obra e daqueles conceitos de presença constante nas obras, que perpassam todo o pensamento do Círculo e são responsáveis pela articulação conceitual ${ }^{10}$. Neste sentido, os artigos que apresentam uma apropriação restrita não contextualizam os conceitos com o todo da obra e/ou não explicitam os conceitos mais fundamentais. A superficialidade desta apropriação é marcada ainda, como se exemplificará na próxima seção, por equívocos conceituais, pela inconsistência de perspectivas aportadas juntamente ao pensamento bakhtiniano (às vezes mais de uma) e pela própria dificuldade em diferenciá-lo com relação a elas (como acontece, algumas vezes, quando a $A D$ Francesa é abordada concomitantemente). Muitas vezes há pouco rigor teórico, o que implica, ainda, a inexistência de metodologia e análises efetivamente relacionadas com o pensamento bakhtiniano. Corriqueiramente os conceitos ficam em segundo plano, pois alguns trabalhos trazem, na verdade, desenvolvimentos teóricos de outras pesquisas ancoradas nas ideias do Círculo. Há ainda 10\% dos trabalhos que têm uma apropriação do tipo "fantasia", isto é, nossa análise sugere que o pensamento bakhtiniano serve apenas para dar "beleza" a esses trabalhos, de forma que se ele for desnudado dessa perspectiva teórica sua essência não muda, podendo receber qualquer outra máscara como referencial. São trabalhos em que nitidamente não se percebe o sentido de utilização do pensamento bakhtiniano, sendo pouco construtivo para a investigação, na qual o que é feito não caracteriza necessariamente uma produção com Bakhtin, poderia estar fundamentada em qualquer outro referencial, por exemplo. $\mathrm{O}$ pensamento bakhtiniano é para constar! Entendemos que essa apropriação acontece pelo desejo de garantir ao trabalho uma "legitimação" (vazia, é claro) ou pelo próprio "modismo", comum em todas as áreas de pesquisa.

Felizmente, nossas análises apontam que o restante da produção (60\%) representa apropriações mais consistentes do pensamento bakhtiniano. Em 25\% dos trabalhos analisados não percebemos a superficialidade teórica comum a outras formas de apropriação, entretanto, há algum nível de desarticulação em relação ao todo da investigação desenvolvida, o que consideramos ser, portanto, uma apropriação desarticulada. Já nos 35\% restante dos trabalhos, nossas análises apontam uma apropriação ampliada, na qual percebemos trabalhos com coerência interna, rigor teórico e metodológico e contribuições valiosas para a área. Nos trabalhos com apropriação desarticulada é possível perceber que há a contextualização dos conceitos com relação ao todo que constitui o pensamento bakhtiniano, bem como o desenvolvimento consistente

10 Não estamos propondo, neste caso, que somente seja possível trabalhar com o pensamento bakhtiniano se todas as obras do Círculo forem estudadas (apesar de isso melhorar a compreensão do todo). O que queremos destacar é que a obra do círculo apresenta particularidades como, por exemplo, livros que não foram preparados para a publicação propriamente por Bakhtin, mas que são fruto de uma composição dos editores a partir de textos encontrados; as obras não chegaram de forma cronológica e lógica, a lógica foi baseada no mercado de livros; e, principalmente, os escritos são inter-relacionados, são marcados pela retomada, pela repetição, a partir das quais os sentidos se ampliam. Dito isso, o que nossa posição quer salientar é que na vasta obra do Círculo, pertencentes a diversas disciplinas, há sem dúvida uma unidade, caracterizada por linhas unificadoras e articuladoras que não deveriam ser perdidas de vista, uma vez que sem este fio condutor pode se incorrer em leituras inconsistentes do pensamento bakhtiniano. 
do quadro conceitual, entretanto, muitas vezes esses conceitos não aparecem, por exemplo, nas análises: são esquecidos no decorrer da pesquisa. Às vezes os conceitos bakhtinianos são solapados por outras perspectivas que são trazidas concomitantemente, de modo que a análise dos dados e interpretação dos resultados fica a cargo destas últimas. Há, portanto, uma contribuição parcial do referencial. Quando não há exclusão dos conceitos no desenvolvimento da análise, se verifica, em algumas situações, a restrição da mesma a apenas um conceito isolado ou, até mesmo, à aplicação de conceitos como categorias de análise. Análises superficiais ou mecânicas, dadas sistematicamente pelo forjamento dos dados a categorias pré-estabelecidas não são raras neste tipo de apropriação $^{11}$. Por vezes não se vislumbra uma metodologia compatível ou, como seria desejável, inspirada no pensamento bakhtiniano. Assim, entendemos que esses elementos quebram com a organicidade que seria desejável ao trabalho, fragiliza a instauração de uma coerência interna que culmine na articulação das dimensões teórica e metodológica, por isso, é desarticulada dentro dessas condições apresentadas e em diferentes graus.

Por fim, estes elementos não são evidentes nos trabalhos que apresentam uma apropriação ampliada, uma vez que esses não recaem em apropriações superficiais e, muito menos, apresentam desarticulações sérias em sua estrutura. Gostaríamos neste momento de comentar alguns desses trabalhos com esta apropriação que muito nos ensinam sobre o pensamento bakhtiniano, entretanto, devido à limitação de espaço, vamos apenas sinalizar algumas dessas produções para que nosso leitor possa compreender melhor as palavras que a ele direcionamos. Sobre a temática formação de professores consideramos um belo exemplo de apropriação ampliada o trabalho identificado com o número 35, no qual se analisam os sentidos atribuídos por professores ao ensino por investigação; sobre a temática processos e materiais educativos o artigo de número 57, no qual uma primorosa análise de livros didáticos é desenvolvida; sobre questões teóricas e metodológicas da pesquisa em Educação em Ciências destacamos o artigo número 10, que apresenta questões teórico-metodológicas de uma pesquisa e discute acerca da objetividade na Educação em Ciências; sobre a temática linguagens e discurso, o trabalho número 23. Destacamos, é claro, que são apenas alguns trabalhos de nosso corpus que fornecem uma apropriação ampliada do pensamento bakhtiniano, apresentados a título de exemplo.

\section{Aprofundamento da análise}

De forma a aprofundar nosso estudo, apresentamos alguns elementos emergentes da análise crítica desenvolvida sobre material empírico, buscando apontar, em função de limitação do espaço, apenas as questões que parecem mais essenciais e elucidativos do que se propôs a investigar nesse trabalho. Referimo-nos a algumas questões conceituais

11 Discutimos essa proposição adiante, contudo, destacamos neste momento que nosso entendimento é de que em Bakhtin se verifica um pensamento antimecanisista, desta forma, consideramos que tais metodologias ficam fragilizadas, pois desconsideram um aspecto basilar que perpassa o pensamento bakhtiniano. 
identificadas e a alguns aspectos metodológicos e analíticos, questões que parecem exigir maior discussão/aprofundamento para ampliar a compreensão sobre o diálogo traçado entre a área de Educação em Ciências e o pensamento bakhtiniano, bem como o entendimento das apropriações do pensamento bakhtiniano que propomos a partir dos trabalhos do nosso corpus.

\section{Fragilidades" conceituais}

Ao analisarmos os artigos da área de Educação em Ciências relacionados ao pensamento bakhtiniano percebemos que a base conceitual de determinados trabalhos é marcada por uma tendência de apresentar alguns conceitos como "naturalizados", isto é, conceitos são mencionados com bastante frequência sem serem desenvolvidos, sem terem seu significado no contexto da obra do Círculo explorado, como se seu entendimento estivesse naturalmente dado pela simples evocação. Percebemos que esse fenômeno, imbricado com a superficialidade conceitual que identificamos em algumas apropriações, ocorre com os conceitos de voz, dialogismo, polifonia e gêneros do discurso. Vamos tomar alguns desses conceitos para exemplificar essa tendência. O conceito de voz é bastante elucidativo desse fenômeno verificado, uma vez que ao mesmo tempo em que sua menção é bastante frequente carece de aprofundamentos. Fenômenos relacionados a este conceito são evocados nos trabalhos a partir de expressões como "reproduzir a voz do professor", "hibridizar vozes", "conflito de vozes", "presença de vozes" etc., entretanto, a ausência de elaboração conceitual acerca desse conceito em uso fragiliza a compreensão de tais fenômenos, além de implicar acepções equivocadas com relação ao conceito de voz. Se por um lado o significado de voz pode, mesmo que superficialmente, ser apreendido simplesmente pelas características procedentes desses fenômenos em que está envolvido, o conceito de polifonia nesses casos de naturalização mostra-se em uma situação mais delicada, pois nem características que deem indicativos mínimos de seu significado são vislumbradas, uma vez que este é utilizado apenas como característica de entidades, tal como "discurso polifônico", "ambiente polifônico", "enunciado polifônico". Mas poderíamos nos perguntar: o que significa "polifônico" segundo Bakhtin? Sem o tratamento adequado do real significado de polifonia seu uso fica injustificado e seu sentido esvaziado. Lembramos ainda que os conceitos de voz e polifonia também estão presentes em outras perspectivas teóricas, como a de Ducrot, por exemplo, mas com significados não completamente alinhados (Amorim, 2004). Assim, a falta de um desenvolvimento adequado em torno desses termos nos trabalhos, nos parece que, além conduzir a superficialidades teóricas, pode levar a confusões conceituais sérias. Outro termo de uso naturalizado e, talvez, acrítico é o "dialógico": percebemos nos trabalhos uma vasta teia de adjetivações como "fios dialógicos", "relação dialógica", "fundo dialógico", "ressonâncias dialógicas", "processo dialógico", "discurso dialógico", sem a delimitação do real significado que as relações dialógicas assumem na obra do Círculo. O termo dialogismo tornou-se tão banalizado que em alguns artigos verificou-se no resumo a proposição de considerá-lo o principal conceito imbricado no 
trabalho, mas, ao mesmo tempo, estando completamente ausente no desenvolvimento da pesquisa. Estes são alguns exemplos de conceitos que aparecem de forma naturalizada, como se sua compreensão fosse claramente óbvia e simples, sem que seu significado seja suficientemente abordado nesses trabalhos. Talvez esses elementos percebidos na área de Educação em Ciências apontem para o fenômeno destacado por Faraco (2009, p. 15) acerca da recepção das obras do Círculo no Brasil: "em especial pelo viés pedagógico (mas não apenas), houve uma banalização de termos como diálogo, interação e gêneros do discurso, retirados do vocabulário do Círculo, mas claramente despojados de sua complexidade conceitual".

Também encontramos nos trabalhos da área algumas formas de compreender as ideias do Círculo bakhtiniano que nos parecem não tão próximas às interpretações mais estabilizadas. Embora o conceito de voz não tenha parecido tão problemático nos trabalhos que o concebem de forma não naturalizada, percebemos uma carência de desenvolvimentos mais aprofundados, uma vez que, em geral, sua abordagem fica limitada a uma definição rápida e direta. Nos parece que, em função da centralidade que este conceito tem assumido nos trabalhos da área, não deveria ter sua complexidade conceitual enxugada.

Uma proposição relacionada ao conceito de vozes que consideramos equivocada assenta-se na ideia de que em Bakhtin existe o conceito de ventrilocução para explicar a relação entre as vozes de sujeitos diferentes: "Bakhtin denomina de ventrilocução o ato de falar através de uma linguagem social, indicando que as palavras utilizadas são repetidas de contextos sociais que não são neutros e imparciais". Inicialmente nos chamou a atenção o fato de nunca termos encontrado nos escritos do Círculo este termo que alguns trabalhos da área afirmam ser uma proposição de Bakhtin. Assim, diante disso, fizemos uma pesquisa por este termo em um site de buscas para compreender um pouco melhor como aparece nos trabalhos e qual sua origem. Inicialmente destacamos que nossas buscas recaíram essencialmente em produções da área de Educação em Ciências, parecendo ser um uso característico desta e pouco frequente em outras áreas. Ainda, como suspeitávamos, percebemos que, na verdade, este não é um conceito trazido pelo Círculo bakhtiniano, mas uma analogia desenvolvida por Michael Holquist (Bubnova, 2011) que nossa área equivocadamente tem utilizado como se fosse uma proposição de Bakhtin. Além disso, como aponta Bubnova (2011), esta analogia não é muito feliz, pois na verdade não existe diálogo entre o ventríloquo e sua marionete, uma vez que esta última não tem voz própria e muito menos o direito de dirigir a fala:

Na verdade, não é uma metáfora muito feliz, porque o ventríloquo só imita um verdadeiro diálogo entre sua marionete e ele mesmo. Na palavra a duas vozes, entram em co(a)lisão duas vozes, dois pontos de vista, duas opiniões, e o ângulo de sua mútua refração pode oscilar, em uma infinita gradação, desde a possibilidade de estar de acordo até uma franca subversão, negação oculta e escândalo mitigado pela escrita, mas que se faz ouvir nas vozes sociais que integram o material primário com que um autor trabalha (Bubnova, 2011, p. 278). 
Outro equívoco identificado na área e que está relacionado à noção de voz é o tratamento dos conceitos de heteroglossia e polifonia como equivalentes. Este entendimento marcado, por exemplo, por expressões como: "Bakhtin denomina polifonia a presença de uma multiplicidade de vozes no discurso de um indivíduo", é comum nos trabalhos. Porém, fica claro que a ideia explícita nesta expressão não designa a polifonia bakhtiniana, mas sim a heteroglossia, que aponta para a heterogeneidade da linguagem. Um conceito responsável por indicar a multiplicidade de vozes sociais que constituem a linguagem, permitindo compreendê-la como um fenômeno estratificado, não apenas no sentido comum, que envolve estratificações produzidas por variedades sociais, temporais e geográficas, mas, fundamentalmente, por "índices sociais de valor oriundos da diversificada experiência socio-histórica dos grupos sociais" (Faraco, 2009, p. 57). Assim, embora a polifonia, no seu significado etimológico, remeta à multiplicidade de vozes, dentro do contexto da obra de Bakhtin não apresenta tal acepção, que estaria mais alinhada ao que condiz com heteroglossia para o Círculo. Neste sentido, "é inadequado não distinguir os termos aqui principalmente porque a estratificação socioaxiológica da linguagem não gera necessariamente uma realidade polifônica. Polifonia não é, para Bakhtin, um universo de muitas vozes, mas um universo em que todas as vozes são equipotentes" (Faraco, 2009, p. 77). Bakhtin toma emprestado a palavra polifonia da música e a utiliza metaforicamente para qualificar o projeto estético realizado por Dostoievski, definindo-o como um novo gênero romanesco, o romance polifônico (Tezza, 2002). O que Bakhtin observou no romance polifônico de Dostoievski é que ele não se caracteriza unicamente pela heteroglossia, não é simplesmente a presença das vozes, mas vozes que são imiscíveis e que figuram em pé de igualdade, equipolentes; as vozes das personagens têm independência com relação à estrutura da obra.

Em suma: o romance polifônico é uma estrutura complexa, cujos heróis, cada um portador de um ponto de vista enraizado numa situação concreta da vida, são autônomos e inacabados com relação ao olhar do autor sobre eles; todos vivem um presente perpétuo, uma coexistência dramática, não finalizada e não finalizável; não se definem pela biografia nem são determinados pelo passado; eles vivem o evento da vida - mas não o vivem diretamente (ou não teríamos obra de arte); eles são representados nessa dimensão, por um autor que se relaciona com eles em pé de igualdade. Eis o romance polifônico segundo Bakhtin, aqui retratado em pinceladas ligeiras (Tezza, 2002, p. 62).

E é exatamente por essas características que o romance polifônico é muito difícil de ser encontrado e, como aponta Tezza (2002), mesmo que talvez de forma radical, mas certamente como uma perspectiva mais segura, a polifonia (em sua plenitude) é uma exclusividade de Dostoievski, tanto que Bakhtin a utiliza apenas na obra que se refere a ele. Diante disso questionamos a consistência de algumas tendências verificadas na área com relação a este tópico: (i) uso de slogans generalizantes - "enunciados polifônicos", "situação de polifonia", "discurso polifônico"; (ii) a busca pela polifonia em enunciados que são analisados. Na maioria das vezes estes trabalhos, talvez pela falta de rigor epistemológico, equivocadamente, tratam, conforme apontamos, da polifonia como 
heteroglossia (exemplo: "os discursos dos títulos e ementas das oficinas são enunciações polifônicas e, como tal, permitem ver os diálogos travados entre diferentes discursos, entre diferentes vozes"). Por outro lado, mesmo supondo clara a distinção entre esses dois conceitos em alguns desses trabalhos, nos parece pouco consistente a referência e a busca pela polifonia, tendo em vista sua raridade. Parece que a área acompanha um movimento identificado por Tezza (2002):

Transformada em moda, a polifonia bakhtiniana perde o seu sentido de origem e se torna exatamente aquilo que negava: uma instância narrativa estrutural da literatura ou da linguística, confundindo-se, muitas vezes com simples intertextualidade; torna-se um conceito reiterável, passa a ser um modelo a se aplicar em qualquer narrativa com dois ou três pontos de vista gramaticais distintos (Tezza, 2002. p. 60).

Ou seja, o que se aponta é o uso da polifonia como um termo técnico com vistas à análise, um conceito abstrato que pode ser aplicado a qualquer discurso, como uma categoria reiterável, exatamente como encontramos em alguns trabalhos da área de Educação em Ciências e exemplificamos: "A análise do discurso dos professores baseia-se na "metalinguística" de Mikhail Bakhtin, utilizando sobretudo os conceitos de apropriação do discurso do outro e polifonia"; "Também será buscada a presença de vozes que levam à concepção de polifonia ou monofonia dos enunciados, resultantes das entrevistas realizadas com os APs". Contudo, estamos cientes que diferentes leituras acerca dessa questão são possíveis, se por um lado parece razoável e mais seguro propor que a polifonia só é encontrada na obra de Dostoievski, também pode ser razoável que alguns elementos característicos da polifonia podem ser encontrados fora dessa obra, ou seja, que elementos ou nuances polifônicas possam ser percebidas em alguns enunciados. Contudo, concordamos com Faraco (2009) e Tezza (2002) de que o conceito de polifonia é analiticamente pouco produtivo, tem menos funcionalidade que o plurilinguismo, por exemplo, e se aproxima mais de uma categoria filosófica do que literária. Assim, é muito mais que uma simples metáfora utilizada para definir a obra de Dostoievski (como afirmamos anteriormente):

No fundo, a polifonia, além de ilustrativa da filosofia do ato de Bakhtin (como defende Tezza), pode ser vista também como metáfora que recobre a sua utopia e que ele viu materializada no projeto artístico de Dostoievski - um mundo de vozes plenivalentes em relações dialógicas infinitas. Talvez, por tudo isso, fosse mais prudente mesmo retirar o termo polifonia do vocabulário crítico de Bakhtin e transferi-lo para seu vocabulário utópico. Pelo menos, poderíamos destrivializar seu uso e aprender mais com a nitidez das coordenadas que o sustentam (Faraco, 2009, p. 79, grifos do autor).

Por fim, nossas análises apontam outra fragilidade com relação ao conceito de polifonia que é sua relação com o dialogismo. Como aponta a literatura, não raramente, estes conceitos são utilizados como sinônimos cuja diferenciação, em função do limite a que precisamos respeitar, não apontaremos neste trabalho, mas claramente,

Bakhtin usa duas palavras diferentes porque se trata de duas coisas diferentes, pertencentes a dois planos diferentes: a polifonia é uma criação artística, uma visão; o 
dialogismo é o aspecto que a polifonia do romance deixou ver do homem e de sua vida (Ponzio, 2010, p. 325).

Diante disso, destacamos que foi possível observar em alguns trabalhos do nosso corpus a ideia de que "as relações dialógicas de um enunciado são polifônicas", o que evidentemente, é uma confusão. A polifonia, sem dúvida, tem como base as relações dialógicas, mas o contrário disso não parece razoável, uma vez que a polifonia apresenta, como brevemente discutimos, um conjunto de características bastante específicas (inconclusibilidade temática, independência, imiscibilidade e equipolência de vozes) que não são vislumbradas em quaisquer relações dialógicas.

Outro equívoco percebido em alguns trabalhos do nosso corpus é a atribuição do termo intertextualidade à Bakhtin e, neste sentido, esclarecemos,

No Brasil, essa "adaptação" vem contribuindo para a deformação do pensamento bakhtiniano em escala temível. Citemos ao menos um exemplo. No livro Intertextualidades (Belo Horizonte: Lê, 1995), de G. Paulino, I. Walty e M. Z. Curry, lemos: "a intertextualidade foi estudada primeiramente pelo pensador russo Mikhail Bakhtin" (p. 21). E as autoras citam minha tradução de PPD como fonte bibliográfica. Em que página do livro aparece o termo "intertextualidade", caríssimas caras-pálidas, que eu, o tradutor, nunca o encontrei? (Bezerra, 2013, p. xx-xxi).

Como havíamos destacado previamente, a intertextualidade, vocábulo introduzido por Kristeva, passou a ser utilizada no lugar de dialogismo, equivocadamente, como apontam Ponzio (2010) e Bezerra (2013). Kristeva, ao confundir palavra com texto - que considera uma entidade desprovida de subjetividade - reduz as noções de intersubjetividade e dialogismo à intertextualidade - relação de um texto com outro texto - incorrendo em um grande equívoco, pois para Bakhtin "o texto é um enunciado, o diálogo entre textos é um diálogo entre enunciados, e por trás do enunciado existe o falante, o sujeito dotado de consciência" (Bezerra, 2013, p. XVII). Logo, o apagamento do sujeito dado pela substituição da intersubjetividade por intertextualidade contradiz o pensamento bakhtiniano, que justamente enfatiza o papel do sujeito como autor, como ser ativo.

Um exemplo dos equívocos causados pela substituição de dialogismo por intertextualidade é apontado por Ponzio (2010) na obra do grande disseminador das ideias de Bakhtin: Torodov. Ao promover essa substituição, o termo dialógico passou a ser reservado apenas a alguns casos de intertextualidade, atribuindo a “diálogo' e 'dialógico' o sentido de intercâmbio habitual entre interlocutores e o de qualidade pessoal que consiste na abertura à palavra e ao ponto de vista do outro, na disponibilidade de escuta" (Ponzio, 2010, p. 316). Quando o diálogo, na concepção do Círculo, não é uma simples concessão do sujeito, não consiste em uma abertura ao outro, "o diálogo, para Bakhtin, não se empreende; se sofre” (Ponzio, 2010, p.223). O diálogo não deve ser associado simplesmente a consenso. Trazemos essa discussão exatamente para apontar a presença dessa ideia equivocada na área: "Para o autor [Bakhtin], os diálogos são produtores de consenso e a interação entre o enunciador e o enunciatário pode se dar de forma direta ou 
indireta, por meio de uma dialogicidade entre os próprios discursos".

\section{Aspectos metodológicos}

Uma característica que se mostrou presente em alguns trabalhos do pensamento bakhtiniano na área de Educação em Ciências e que ajudam a compreender algumas apropriações foi a atribuição de uma perspectiva puramente metodológica às ideias do Círculo. Percebemos que, embora a maioria dos trabalhos se refira ao pensamento bakhtiniano como um referencial teórico-metodológico, no desenvolvimento de algumas pesquisas fica clara sua associação a uma metodologia puramente de análise de dados. Como se pode observar, por exemplo, pela ideia transmitida pelo seguinte trecho extraído de um artigo do nosso corpus: "A seguir, aprofundamos nossa análise sobre o compartilhamento de significado e a mediação do interlocutor na aula de Física. Para isso, tomamos, como um referencial analítico-interpretativo, algumas ideias relacionadas à linguagem apresentadas pelo filósofo russo Mikhail Bakhtin (2006), e, ainda, consideramos, em nossas reflexões, um levantamento de termos apresentados em alguns dicionários de Libras." Em geral, os trabalhos com essas apropriações não se valem do pensamento bakhtiniano como uma visão de mundo que, sem ser aplicada, mas apreendida pelo pesquisador, situa o caminhar da pesquisa, o modo de olhar para os fenômenos e estabelece o fio condutor que delimita os pressupostos que fundamentam a pesquisa desde a concepção do problema até as interpretações dos resultados, passando, obviamente, pelas orientações metodológica e analítica. Neste sentido, apontamos que raramente o pensamento bakhtiniano aparece como único referencial nos trabalhos do nosso corpus e, em geral, a ênfase dada a ele é na questão analítica, como uma perspectiva que permite dar conta do estudo da linguagem, ao passo que esta constitui o corpo empírico dos trabalhos. Ideias como "Utilizou-se, como principal referencial, a teoria sócio-histórica de Vigotski e a análise de discurso proposta por Bakhtin", exemplificam um pouco do que estamos apontando. Neste sentido, destacamos que, embora a linguagem constitua o cerne do pensamento bakhtiniano, não o limita, pois este também pode ser visto como uma "filosofia de valores, uma filosofia da vida e uma filosofia da interação" (Faraco, 2017, p. 55). Ou seja, defendemos que o pensamento bakhtiniano não deva ter sua presença justificada nos trabalhos unicamente por dar conta da questão da linguagem, pois nos parece que, sob um entendimento mais aprofundado deste, consiste em uma visão de mundo que possibilita dar conta de uma gama variada de fenômenos das ciências humanas.

A questão é que assumí-lo como um referencial puramente metodológico pode sugerir uma concepção de método bakhtiniano e, consequentemente, recair em uma visão positivista de pesquisa incoerente com a heterocientificidade de Bakhtin. Por outro lado, é importante destacar uma percepção sobre os trabalhos que assumem o pensamento bakhtiniano como referencial teórico-metodológico, também já apontada por Pinhão e Martins (2008, p. 6), de que, “(...) apesar disso [considerar como referencial teóricometodológico], o nível de explicitação do desenho metodológico, em alguns momentos, 
se restringe à nomeação de categorias a serem utilizadas. Como consequência, ocorre uma espécie de apagamento do caminho percorrido pelo pesquisador para chegar as suas conclusões". Isso poderia, de certa forma, afastar esses trabalhos da visão de pesquisa sob a perspectiva bakhtiniana.

Apontamos, neste caso, que não é raro encontrar nos trabalhos do nosso corpus desenhos metodológicos baseados na criação de categorias (relacionadas com o pensamento bakhtiniano ou não) definidas a priori para posterior aplicação. Por exemplo: "A metodologia empregada envolveu a aplicação de um sistema de categorias proposto por Mortimer, Massicame, Buty e Tiberghien (2005 a e b) aos dados de sala de aula registrados em vídeo, em tempo real, utilizando um software desenvolvido pelo IPNKiel, o Videograph ${ }^{\circledast}$. Neste sentido, sem discutir a complexa questão de metodologia no pensamento bakhtiniano, entendemos que não parece razoavelmente coerente a proposição de desenhos metodológicos fechados e pautados pela aplicação de categorias prévias que se sobrepõem aos dados, incorrendo no estabelecimento de dinâmicas mecanicistas no seu sentido de encaixar os dados às categorias, compartimentalizar, classificar, como um método, quase positivista. Percebemos na arquitetônica bakhtiniana a negativa ao pensamento mecanicista e ao fechamento, em favor da abertura, do movimento, das interações, da escuta e, neste sentido, é razoável apontar que não é o uso de categorias analíticas que deve perseguir os dados, mas estes últimos que implicam a emersão de categorias, a partir de suas formas de se constituir e revelar sentido. Bakhtin (2011) em sua crítica ao mecanicismo, opõe mecânico a aquilo que está impregnado pela unidade interna de sentido, apontando que o mecânico é carente de interações, é impermeável a influências: é mecânico "se alguns de seus elementos estão unificados apenas no espaço e no tempo por uma relação externa e não os penetra a unidade interna do sentido. As partes desse todo, ainda que estejam lado a lado e se toquem, em si mesmas são estranhas umas às outras" (Bakhtin, 2011, p. XXXIII). Assim, uma peculiaridade metodológica da área de Educação em Ciências, o uso de dispositivos analíticos, pode se constituir em um caminho contrário aos pressupostos bakhtinianos quando encarada de forma mecânica. Em acordo à crítica já levantada pela literatura:

Consideramos que o uso da análise do discurso ${ }^{12}$, quando pautado apenas na aplicação de categorias analíticas, fora de considerações de natureza sócio-histórica, equivoca-se e esvazia a teoria. Em consequência pouco colabora para a consolidação de um corpo teórico metodológico para o campo da pesquisa em ensino de ciências. Este é, por exemplo, o caso de alguns trabalhos que utilizam o modelo de análise proposto por Mortimer e Scott (2002) e a Análise textual discursiva de Moraes e Galiazzi (2003)

12 Neste trabalho as autoras realizaram uma revisão de artigos publicados em revistas brasileiras da área EC que fazem uso de uma vertente de análise do discurso. Embora a teoria de Bakhtin não se constitua como um tipo de análise do discurso, este autor foi citado como referência na construção do quadro teórico de pelo menos metade dos artigos analisados pelas autoras, portanto, neste caso, elas se referem também a trabalhos que fazem análises fundamentadas nos pressupostos de Bakhtin. Dentre os aspectos estudados está: "a forma pela qual a análise do discurso era mobilizada no artigo (referencial teórico-metodológico, referencial metodológico ou referencial teórico)" (p. 4). 
apenas como uma ferramenta analítica, sem problematizar a natureza do discurso ou explicitar pressupostos teóricos. Apesar destes trabalhos se constituírem em ferramentas metodológicas não devem ser usados apenas como uma técnica, pois não reflete o real valor dos mesmos enquanto tentativas de teorização no campo (Pinhão, \& Martins, 2008, p. 6).

Apontamos a referência a dois dispositivos de análise com inspiração bakhtiniana nos trabalhos do nosso corpus: Mortimer \& Scott (2002) e Veneu (2012). Tais dispositivos se constituem em duas propostas bastante diferentes sob o ponto de vista de construção e utilização: enquanto o primeiro é mais focado no estabelecimento de categorias analíticas fechadas, o segundo se preocupa mais com o estabelecimento de etapas de análise dotadas de certa plasticidade. Apesar disso, destacamos a prevalência do primeiro dispositivo nos trabalhos do nosso corpus, sendo o artigo no qual ele é apresentado citado em, pelo menos, 17 trabalhos. Essa prevalência possivelmente esteja ligada a aqueles fatores que demarcam o início dos estudos bakhtinianos na área.

Outra questão metodológica identificada em algumas apropriações é a desconexão do desenho metodológico da pesquisa com relação ao pensamento bakhtiniano, de forma que se verifica proposições sem fundamentação no referencial ou, até mesmo, incoerentes com o mesmo. Para exemplificar, trazemos uma situação que demonstra a desconexão entre o referencial e o desenho metodológico, mas, mais do que isso, aponta para a inconsistência de perspectivas: "Para a análise das transcrições realizadas, apoiou-se nas contribuições metodológicas da Análise Textual Discursiva, proposta por Moraes e Galiazzi (2007), pois nos interessávamos pela dinâmica das “interações” nas reuniões”. Ou seja, são trazidas perspectivas com bases epistemológicas diferentes, que não se alinham, como se pudessem ser simplesmente sobrepostas, sem rigor metodológico algum. Ademais, nos parece que trazer a ATD para a análise dos dados em um trabalho fundamentado pelo pensamento bakhtiniano indica uma apropriação limitada deste último e tende a torná-lo irrelevante no trabalho. Da mesma forma, identificamos outras associações que, embora não analisaremos aqui, suspeitamos poderem ser potencialmente inconsistentes ou pouco harmonizadas: é o caso das combinações que encontramos nos trabalhos do pensamento bakhtiniano com a ADF, com a teoria da enunciação de Ducrot, com a linguística sistêmico-funcional de Halliday e a já mencionada ATD. Por fim, destacamos a fraca presença de proposições de desdobramentos metodológicos a partir do pensamento bakhtiniano nos trabalhos, de forma que não se percebeu contribuições significativas neste sentido.

\section{Análise bakhtiniana?}

Por fim, o último elemento sobre o qual nos debruçaremos diz respeito às análises empregadas nos trabalhos. Neste sentido, apontamos que as análises são desenvolvidas de formas variadas como era de se esperar, entretanto, uma questão crucial revelada em algumas apropriações identificadas é a concepção de que o Círculo bakhtiniano propôs um método de análise, o que tem sido chamado por alguns trabalhos de "análise de 
discurso proposta por Bakhtin". Sobre este aspecto, sabe-se que o Círculo nunca teve a pretensão de elaborar uma teoria de Análise do Discurso, ou seja, "ao percorrermos os textos do Círculo de Bakhtin não nos deparamos, em nenhum momento, com a formalização de um método científico propriamente dito, mas com grandes diretrizes para construirmos um entendimento mais amplo das realidades sob estudo" (Faraco, $2009,40)$. Por esses mesmos motivos entendemos como equivocado propor que existe uma análise bakhtiniana, uma vez que isso pode sugerir que o Círculo tivesse deixado como contribuição um método de análise. Preferimos guardar este termo para descrever as análises desenvolvidas por Bakhtin, por exemplo, nas obras referentes a Dostoievski e Rabelais. Por outro lado, parece razoável que se possa pensar em construções metodológicas (e não um método) a partir do pensamento bakhtiniano e das análises desenvolvidas pelos membros do Círculo. Neste sentido, no Brasil tem se proposto que o conjunto das obras do Círculo motivou o surgimento da chamada Análise Dialógica do Discurso (ADD) (Brait, 2006), uma perspectiva dialógica de análise que tem como fundamento o pensamento bakhtiniano e, neste sentido,

As contribuições bakhtinianas para uma teoria/análise dialógica do discurso, sem configurar uma proposta fechada e linearmente organizada, constituem de fato um corpo de conceitos, noções e categorias que especificam a postura dialógica diante do corpus discursivo, da metodologia e do pesquisador. A pertinência de uma perspectiva dialógica se dá pela análise das especificidades discursivas constitutivas de situações em que a linguagem e determinadas atividades se interpenetram e se interdefinem, $e$ do compromisso ético do pesquisador com o objeto, que, dessa perspectiva, é sujeito histórico (Brait, 2006, p. 29).

Nessa forma de conceber a chamada ADD percebemos uma característica que julgamos fundamental diante do pensamento bakhtiniano e que é a base das nossas críticas a análises desenvolvidas em algumas apropriações identificadas: não é possível aplicar as ideias do Círculo bakhtiniano, mas pensar a partir delas (Ponzio, 2010). Além disso, o que se observa na ADD é a inexistência de regras fechadas, de linearidade, de protocolos a serem seguidos, o que, de certa forma, contrasta bastante com algumas análises desenvolvidas a partir de dispositivos analíticos nos trabalhos do nosso corpus. Neste sentido, é razoável propor que os dispositivos analíticos podem se enquadrar mais facilmente em uma perspectiva de aplicação do pensamento bakhtiniano. Uma forma de compreender melhor a questão analítica a partir de Bakhtin pode ser a partir das próprias análises desenvolvidas por ele, por exemplo, nos livros sobre Dostoievski e Rabelais. Nestas obras não se verifica a definição de categorias pré-estabelecidas e sua posterior aplicação de forma mecânica para compreender as formas de produção de sentido, percebemos um caminho oposto: o conceito de polifonia, por exemplo, emerge a partir da análise do corpus discursivo, isto é, Bakhtin "não tinha um conceito ad hoc de polifonia para testar nos escritos de Dostoievski. É a partir dos textos de Dostoievski que o conceito é formulado, constituído" (Brait, 2006, p. 24). Diante disso é que propomos que em análises feitas a partir do pensamento bakhtiniano "não há categorias a priori, 
aplicáveis de forma mecânica a textos e discursos, com a finalidade de compreender formas de produção de sentido num dado discurso, numa dada obra, num dado texto" (Brait, 2006, p. 14). E mais do que isso, é possível reconhecer um desdobramento analítico a partir das obras do Círculo:

chegar a uma categoria, a um conceito, a uma noção, a partir da análise do corpus discursivo, dos sujeitos e das relações que ele instaura. (...) Não aplicar conceitos a fim de compreender um discurso, mas deixar que os discursos revelem sua forma de produzir sentido, a partir de ponto de vista dialógico, num embate (Brait, 2006, p. 24).

É com base nessa postura axiológica frente ao pensamento bakhtiniano, que obviamente não é a única e não se propõe como a "correta", que consideramos pouco consistentes as análises desenvolvidas em nossa área de forma mecânica, a partir de protocolos, com proposição de categorias que forçam os dados, que são aplicadas sobre estes; que muitas vezes se limitam a associações simples e diretas entre palavras ou se dão a partir da elaboração de paráfrases (unidade repetível e que elimina sentidos); ou que fragmentam e isolam o contexto. Além disso, uma questão fundamental vislumbrada na forma de analisar fenômenos pelo Círculo e que assumimos como primordial em qualquer trabalho fundamentado neste: "consiste em colocar em relação campos e objetos de estudo mesmo distantes através de um processo de deslocamento e abertura, mais do que de incorporação e de fechamento" (Petrilli, 2013, p. 134). Neste sentido, procuramos nos trabalhos o estabelecimento de relações na constituição das análises e percebemos que estas nem sempre se fazem presentes.

Por fim, se algumas análises podem ter ficado completamente descaracterizadas pelo fato de não se identificar a presença de conceitos iluminando-as, há outras em que os conceitos aparecem, mas são equivocadamente propostos e aplicados como categorias de análise: "Realizando uma análise documental de caráter qualitativo, com a leitura do livro 'Vinte Mil Léguas Submarinas' e a seleção de alguns trechos, procuramos discutir as relações entre a obra de Júlio Verne e o ensino de Física, tomando como categorias de análise alguns conceitos da teoria de Bakhtin (1997, 2009): gêneros do discurso, tema, significação, réplica e dialogismo". Este processo, como aponta Faraco (2009), é fruto da interpretação dos textos do Círculo por aquilo que não são, transformando o filosófico em categorias científicas. Em outro texto, coloca que isso se relaciona à falta de percepção da filiação ao pensamento dialético existente:

Sem perceber essa filiação, sem adentrar dialeticamente a obra, necessariamente reduziremos Bakhtin, perderemos seu senso de totalidade e cairemos na reificação de suas categorias (dialogismo, carnavalização, polifonia, discurso citado, etc). Nesse sentido, vale para ele, de certa forma, o que ele dizia de Dostoievski: "sem entender a nova forma de visão, é impossível entender corretamente aquilo que pela primeira vez foi percebido e descoberto na vida com o auxílio desta forma" (Faraco, 1988, p. 27)

Portanto, se pode sugerir que tanto quando não se percebe a presença de conceitos iluminando (filosoficamente) a análise, como quando esses são tomados como categorias analíticas, há subjacente dificuldades de dar conta desse pensamento, que não 
pode ser lido a partir da nossa forma cartesiana de pensar, uma vez que opera "com uma forma de pensar que se afasta radicalmente dos paradigmas hegemônicos no mundo acadêmico que estuda as realidades humanas" (Faraco, 2001, p. 113). Talvez a herança positivista, ainda presente na Educação em Ciências, seja um entrave para apropriações mais amplas do pensamento bakhtiniano, uma vez que dificulta visões mais arejadas e o afastamento do mecânico, do protocolo, do calculável, do controlável, do fechamento. Impossibilita entender que não é possível aplicar Bakhtin, mas pensar a partir dele!

\section{É necessário avançar}

Cientes de que este é um ensaio inicial sobre esta temática, bastante breve e sintético em função do limite de páginas delimitado pela revista, destacamos que há aprofundamentos a serem feitos. As discussões que elaboramos ao longo do trabalho não se deram no sentido de esgotar as questões levantadas e, muitas vezes, nem mesmo o suficiente aprofundamento que consideramos adequado. Entretanto, cientes das limitações desse trabalho, entendemos que estamos abrindo um caminho para a discussão da apropriação do pensamento bakhtiniano pela área de Educação em Ciências. Consequentemente, a partir deste ato inaugural, carregado de nossa compreensão sobre as ideias do Círculo e das nossas posturas axiológicas frente a elas (que certamente não podem ser configuradas como "corretas"), esperamos despertar respostas em nossos leitores. Respostas ativas que culminem em novas discussões e aprofundamentos sobre esta questão tão importante. Neste sentido, cientes de que nossas provocações exigem maiores discussões, apontamos possíveis temáticas que poderiam ser abordadas/ aprofundadas. Primeiramente nos parece clara a necessidade de se desenvolver um trabalho com uma análise mais detalhada dos objetivos e das referidas contribuições dos trabalhos que envolvem o pensamento bakhtiniano na área. Da mesma forma, cremos que um artigo focado exclusivamente na análise da apropriação conceitual pela área é crucial para caminharmos em direções a minimizar fenômenos de deturpação, banalização e superficialidade com relação ao pensamento bakhtiniano. Além disso, percebemos que a linha de formação de professores é a que assume as ideias do Círculo com maior ênfase, assim, acreditamos que cabe o desenvolvimento de uma análise da relação estabelecida pela área entre a formação docente e o pensamento bakhtiniano. Ademais, tendo em vista que a falta de metodologias consistentes têm sido um problema bastante corrente na área, entendemos ser crucial o desenvolvimento de um trabalho que realize uma análise que aprofunde as breves digressões que trouxemos sobre a questão metodológica envolvendo o pensamento bakhtiniano nos trabalhos da Educação em Ciências. Por fim, acreditamos que há de se pensar de forma mais profunda a questão da identidade, uma vez que percebemos a discussão sobre esta temática a partir das ideias do Círculo em alguns trabalhos, porém, entendemos que se faz necessário investir melhor nessa discussão pelo fato de ao Círculo importar mais a alteridade ${ }^{13}$ do que a

13 De forma simplista poderia se dizer que alteridade trata da contraposição eu/outro, relação a partir do qual o ser se constitui, isto é, é apenas a partir do "outro" que o "eu" se constitui, mas não como uma mera cópia. 
identidade e a constituição desta última não ser explorada nos trabalhos em razoável sintonia com esse conceito nuclear.

\section{Agradecimentos}

Agradecemos o apoio concedido pelo Instituto Federal do Rio Grande do Sul.

\section{Referências}

Amorim, M. (2004). O pesquisador e seu outro: Bakhtin nas ciências humanas. Musa Editora.

Bakhtin, M. (2011). Arte e responsabilidade. In M. Bakhtin. Estética da Criação Verbal. 6 ed. Martins Fontes.

Bakhtin, M. (1997). Estética da Criação Verbal. 2 ed. Martins Fontes.

Bakhtin, M. (2013). Problemas da Poética de Dostoievski. 5 ed. Forence Universtitária.

Bezerra, P. (2013). Prefácio: uma obra à prova do tempo. In M. Bakhtin, Problemas da Poética de Dostoievski. 5 ed. Forence Universtitária.

Brait, B. (2006). Análise e teoria do discurso. In B. Brait (Org.), Bakhtin: outros conceitoschave (pp. 9-31). Contexto.

Bubnova, T. (2010). Sobre as ruínas de "Bakhtin" ou os perigos da isegoria. In L. Paula, \& G. Stafuzza (Orgs.), Círculo de Bakhtin: diálogos (in)possíveis (pp. 19-32). Mercado de Letras.

Bubnova, T. (2011). Voz, sentido e diálogo em Bakhtin. Bakhtiniana: revista de estudos do discurso, 6(2), 268-280.

Faraco, C. A. (1988). Bakhtin: a invasão silenciosa e a "má leitura”. In C. Faraco. Uma introdução a Bakhtin. Hatier.

Faraco, C. A. (2017). Bakhtin e filosofia. Bakhtiniana: revista de estudos do discurso, $12(2), 45-56$.

Faraco, C. A. (2009). Linguagem e diálogo: as ideias linguísticas do círculo de Bakhtin. Parábola Editorial.

Faraco, C. A. (2001). O dialogismo como chave de uma antropologia filosófica. In C. Faraco, C. Ttezza, \& G. Castro (Orgs.), Diálogos com Bakhtin (pp. 113-126). 3. ed. Editora da UFPR.

Freitas, M. T. A. (2004). O pensamento de Vygotsky nas reuniões da ANPEd (19982003). Educação e Pesquisa, 30(1), 109-138. 
Garcia, J. F. M., \& Lima, M. E. C. C. (2009). A abordagem da linguagem no ensino de ciências em teses e dissertações brasileiras. In Anais do VII Encontro Nacional de Pesquisa em Educação em Ciências. Florianópolis, SC: ABRAPEC.

Geraldi, J. W. (2013). Introdução: o mundo não nos é dado, mas construído. In V. Volochínov. A construção da enunciação e outros ensaios (pp. 7-27). Pedro \& João Editores.

Mortimer, E., \& Scott, P. (2002). Atividade discursiva nas salas de aula de ciências: uma ferramenta sociocultural para analisar e planejar o ensino. Investigações em Ensino de Ciências, 7(3), 283-306.

Nardi, R., \& Almeida, M. J. P. M. (2008). Educación en Ciencias: lo que caracteriza el área de enseñanza de las Ciencias en Brazil según investigadores brasileños. Revista Electrónica de Investigación en Educación en Ciencias, 3, 24-34.

Nicolli, A. A., Oliveira, O. B., \& Cassiani, S. (2011). A linguagem na educação em ciências: um mapeamento das publicações dos ENPECs de 2005 a 2009. In Anais do VIII Encontro Nacional de Pesquisa em Educação em Ciências. Campinas, SP: ABRAPEC.

Petrilli, S. (2013). Em outro lugar e de outro modo. Filosofia da linguagem, crítica literária e teoria da tradução em, em torno de Bakhtin e a partir de Bakhtin. Pedro \& João Editores.

Pinhão, F., \& Martins, I. (2009). A análise do discurso e a pesquisa em ensino de ciências no Brasil: um levantamento da produção em periódicos entre 1998 e 2008. In Anais do VII Encontro Nacional de Pesquisa em Educação em Ciências. Florianópolis, SC: ABRAPEC.

Ponzio, A. (2010). O pensamento dialógico de Bakhtin e de seu Círculo como inclassificável. In L. Paula, \& G. Stafuzza (Orgs.), Círculo de Bakhtin: teoria inclassificável (pp. 293-349). Mercado de Letras.

Romanowski, J. P., \& Ens, R. T. (2006). As pesquisas denominadas do tipo "estado da arte" em educação. Diálogo educaional, 6(19), 37-50.

Seriot, P. (2015). Vološinov e a filosofia da linguagem. Parábola Editorial.

Souza, G. T. (2002). A construção da Metalinguística (fragmentos de uma ciência da linguagem na obra de Bakhtin e seu círculo). Tese (Doutorado em Letras). Faculdade de Filosofia, Letras e Ciências Humanas, Universidade de São Paulo, São Paulo.

Souza, G. S. M., Silva, E. S., Santos, K. N., \& Santos, B. F. (2013). A pesquisa sobre linguagem e ensino de ciências no Brasil em teses e dissertações (2000-2011). In Anais do VIV Encontro Nacional de Pesquisa em Educação em Ciências. Águas de Lindóia, SP: ABRAPEC, 2013.

Tezza, C. (2002). Polifonia e ética. Revista Cult, 59, 60-63. 
Veneu, A. (2012). Perspectivas de professores de física do ensino médio sobre as relações entre o ensino de Física e o mercado de trabalho: uma análise bakhtiniana. Dissertação (Mestrado em Educação em Ciência e Saúde). Núcleo de Tecnologia Educacional para a Saúde, Universidade Federal do Rio de Janeiro, Rio de Janeiro.

\section{Diomar Caríssimo Selli Deconto}

${ }^{\oplus}$ https://orcid.org/0000-0003-3707-7303 Instituto Federal de Educação, Ciência e Tecnologia do Rio Grande do Sul Caxias do Sul, Rio Grande do Sul, Brasil diomardec@gmail.com

Fernanda Ostermann

${ }^{\oplus}$ https://orcid.org/0000-0002-0594-2174 Universidade Federal do Rio Grande do Sul Instituto de Física, Departamento de Física Porto Alegre, Rio Grande do Sul, Brasil fernanda.ostermann@ufrgs.br

Submetido em 03 de setembro de 2019 Aceito em 20 de dezembro de 2020 Publicado em 22 de março de 2020 


\section{Apêndice}

\begin{tabular}{|c|c|c|}
\hline N.I. & Título & Referência \\
\hline 1 & Ensinar, formar, educar e instruir: a linguagem da crise escolar & A $12(2), 2006$ \\
\hline 2 & $\begin{array}{l}\text { Oficinas pedagógicas de ciências: os movimentos pedagógicos predominantes na formação } \\
\text { continuada de professores }\end{array}$ & A $12(3), 2006$ \\
\hline 3 & $\begin{array}{l}\text { Apropriação do discurso de inovação curricular em química por professores do ensino } \\
\text { médio: perspectivas e tensões }\end{array}$ & A 14 (2), 2008 \\
\hline 4 & Qualidade da educação científica na voz dos professores & A $17(2), 2011$ \\
\hline 5 & O discurso sobre a consciência em memoriais de educadores ambientais & A 17 (3), 2011 \\
\hline 6 & A formação de conceitos científicos: reflexões a partir de produção de livros didáticos & A 17 (4), 2011 \\
\hline 7 & Dialogismo, ensino de física e sociedade: do currículo à prática pedagógica & A 19 (2), 2013 \\
\hline 8 & $\begin{array}{l}\text { Contribuições da teoria sócio-histórica para a pesquisa sobre a escolarização de jovens e } \\
\text { adultos }\end{array}$ & A 19 (2), 2013 \\
\hline 9 & $\begin{array}{l}\text { Perspectivas de professores de física sobre as políticas curriculares nacionais para o Ensino } \\
\text { Médio }\end{array}$ & A 20 (2), 2014 \\
\hline 10 & Discutindo a objetividade na pesquisa em educação em ciências & A $20(2), 2014$ \\
\hline 11 & $\begin{array}{l}\text { O compartilhamento de significado na aula de Física e a atuação do interlocutor de Língua } \\
\text { Brasileira de Sinais }\end{array}$ & A $21(2), 2015$ \\
\hline 12 & A prática docente e o dialogismo bakhtiniano: o ensino como um ato responsável & A $21(4), 2015$ \\
\hline 13 & $\begin{array}{l}\text { O estudo das vozes de alunos quando estão envolvidos em atividades de investigação em } \\
\text { aulas de física }\end{array}$ & B $11(2), 2009$ \\
\hline 14 & $\begin{array}{l}\text { Práticas enunciativas em um evento de divulgação científica em um museu de ciências do } \\
\text { Rio de Janeiro }\end{array}$ & B $12(2), 2010$ \\
\hline 15 & Atividades de elaboração conceitual por estudantes na sala de aula de física na EJA & B $12(1), 2010$ \\
\hline 16 & $\begin{array}{l}\text { Tecnologias da informação e comunicação e qualidade da educação na perspectiva de uma } \\
\text { professora de Ciências }\end{array}$ & B 13 (3), 2011 \\
\hline 17 & $\begin{array}{l}\text { Diferenças de gênero nas preferências disciplinares e profissionais de estudantes de nível } \\
\text { médio: relações com a educação em ciências }\end{array}$ & B 13 (2), 2011 \\
\hline 18 & $\begin{array}{l}\text { Controvérsias sobre o aquecimento global: circulação de vozes e de sentidos produzidos } \\
\text { em sala de aula }\end{array}$ & B $14(1), 2012$ \\
\hline 19 & Discursos que circulam na correção de um questionário: sentidos e significados & B $14(3), 2012$ \\
\hline 20 & $\begin{array}{l}\text { A qualidade do ensino de ciências na voz de professores da educação profissional técnica } \\
\text { de nível médio }\end{array}$ & B 15 (3), 2013 \\
\hline 21 & $\begin{array}{l}\text { O impacto de um mestrado profissional em ensino de Física na prática docente de seus } \\
\text { alunos: uma análise bakhtiniana sobre os saberes profissionais }\end{array}$ & B $15(2), 2013$ \\
\hline 22 & $\begin{array}{l}\text { Construção da identidade docente de um estudante de licenciatura em Ciências Biológicas } \\
\text { em curso a distância: um caso de hibridismo }\end{array}$ & B $16(1), 2014$ \\
\hline 23 & É possível argumentação sem controvérsia? & B 17 (E), 2015 \\
\hline 24 & $\begin{array}{l}\text { Análise de discursos no ensino de ciências: considerações teóricas, implicações } \\
\text { epistemológicas e metodológicas }\end{array}$ & B $17(1), 2015$ \\
\hline 25 & Avaliação de estudantes sobre a prática de produzir registros das atividades de ciências & B 17 (1), 2015 \\
\hline 26 & $\begin{array}{l}\text { Apropriação discursiva de modelos de formação docente em trabalhos de conclusão de um } \\
\text { mestrado profissional em ensino de física }\end{array}$ & B $18(2), 2016$ \\
\hline 27 & Cientistas em revista: Einstein, Darwin e Marie Curie na ciência hoje das crianças & B $18(2), 2016$ \\
\hline 28 & $\begin{array}{l}\text { A prática da escrita e da reescrita orientada no processo de significação conceitual em aulas } \\
\text { de Química }\end{array}$ & B $18(2), 2016$ \\
\hline
\end{tabular}

N.I.: número de identificação do artigo; Referência: letra que representa a revista, volume (número), ano. A: Ciência \& Educação; B: Ensaio (...) 


\begin{tabular}{|c|c|c|}
\hline N.I. & Título & Referência \\
\hline 29 & $\begin{array}{l}\text { A implementação da história da ciência no ensino de física: uma reflexão sobre as } \\
\text { implicações do cotidiano escolar }\end{array}$ & B 19, 2017 \\
\hline 30 & $\begin{array}{l}\text { Atividade discursiva nas salas de aula de ciências: uma ferramenta sociocultural analisar e } \\
\text { planejar o ensino }\end{array}$ & C 7 (3), 2002 \\
\hline 31 & A criação e manutenção da intersubjetividade na sala de aula de Química & C 9 (3), 2004 \\
\hline 32 & Apropriação do discurso científico por alunos protestantes de Biologia & C $11(1), 2006$ \\
\hline 33 & Formulação de questões e mediação da leitura & C $15(3), 2010$ \\
\hline 34 & $\begin{array}{l}\text { Caracterizando estratégias enunciativas em uma sala de aula de química: aspectos teóricos } \\
\text { e metodológicos em direção à configuração de um gênero do discurso }\end{array}$ & C $15(1), 2010$ \\
\hline 35 & $\begin{array}{l}\text { A construção de sentidos para o termo ensino por investigação no contexto de um curso } \\
\text { de formação }\end{array}$ & C $16(1), 2011$ \\
\hline 36 & $\begin{array}{l}\text { A formação de conceitos como ascensão do abstrato ao concreto: da energia pensada à } \\
\text { energia vivida }\end{array}$ & C 18 (2), 2013 \\
\hline 37 & $\begin{array}{l}\text { Elaboração de um mapa de caracterização do texto científico: referenciais teóricos e } \\
\text { aplicação em destaque }\end{array}$ & C 20 (1), 2015 \\
\hline 38 & $\begin{array}{l}\text { Características do discruso de divulgação científica: implicações da dialogia em uma } \\
\text { interação assíncrona }\end{array}$ & C $22(2), 2017$ \\
\hline 39 & Revisitando projetos de ensino de Física numa perspectiva bakhtiniana & C $22(3), 2017$ \\
\hline 40 & A linguagem Latex e o ensino de Física para alunos com deficiência visual & C $23(2), 2018$ \\
\hline 41 & $\begin{array}{l}\text { Ciência, política e mídia na perspectiva centrada no esclarecimento: a sociologia de Alan } \\
\text { Irwin em diálogo com a educação em ciências }\end{array}$ & C 23 (1), 2018 \\
\hline 42 & A argumentação em discussões sócio-científicas: reflexões a partir de um estudo de caso & D $1(1), 2001$ \\
\hline 43 & Comunicação não-verbal em sala de aula & D $1(1), 2001$ \\
\hline 44 & $\begin{array}{l}\text { Construyendo puentes y fronteras: caracterización del género discursivo en una clase } \\
\text { universitaria de física }\end{array}$ & D $3(1), 2003$ \\
\hline 45 & Os gêneros de discurso do texto de biologia dos livros didáticos de ciências & D $3(3), 2003$ \\
\hline 46 & $\begin{array}{l}\text { O uso dos conceitos de elemento e substância por estudantes do ensino fundamental: uma } \\
\text { perspectiva de análise sociocultural }\end{array}$ & D $8(3), 2018$ \\
\hline 47 & O discurso ideológico sobre Aristóteles nos livros didáticos de Física & D $9(2), 2009$ \\
\hline 48 & Discurso de estudantes e habitus pedagógico em cursos de graduação em Ciências Naturais & D $11(3), 2011$ \\
\hline 49 & As perguntas em aulas investigativas de ciências: a construção teórica de categorias & D $12(2), 2012$ \\
\hline 50 & $\begin{array}{l}\text { A ação docente como sustentação da produção discursiva dos estudantes na sala de aula de } \\
\text { física de educação de jovens e adultos }\end{array}$ & D $12(1), 2012$ \\
\hline 51 & $\begin{array}{l}\text { O grupo de estudos e discussão como subsídio ao desenvolvimento de interações discursivas } \\
\text { entre professores de física sobre a temática teoria da relatividade }\end{array}$ & D $13(1), 2013$ \\
\hline 52 & $\begin{array}{l}\text { A apropriação do discurso dialógico e os pontos de transição: uma análise a partir da } \\
\text { experiência de professores de Química em formação }\end{array}$ & D $15(2), 2015$ \\
\hline 53 & $\begin{array}{l}\text { Estratégias discursivas adotadas por professores em formação na compreensão do } \\
\text { fenômeno da complementaridade em atividades didáticas mediadas pelo interferômetro } \\
\text { virtual de Mach-Zehnder }\end{array}$ & D $15(2), 2015$ \\
\hline 54 & Interação com Imagens e Gesticulação em uma Aula de Biologia & D $16(3), 2016$ \\
\hline 55 & $\begin{array}{l}\text { A Apropriação do Gênero de Divulgação Científica pelas Crianças: Fragmentos de um } \\
\text { Percurso }\end{array}$ & D 16 (3), 2016 \\
\hline 56 & $\begin{array}{l}\text { A Construção do Sítio Ciência na Comunidade: Antecedentes, Fundamentos, Narrativas } \\
\text { Híbridas e Conteúdo Epistemológico }\end{array}$ & D 17 (1), 2017 \\
\hline
\end{tabular}

N.I.: número de identificação do artigo; Referência: letra que representa a revista, volume (número), ano. A: Ciência \& Educação; B: Ensaio; C: Investigações em Ensino de Ciência; D: Revista Brasileira de Pesquisa em Educação em Ciências; E: Alexandria; F: Caderno Brasileiro de Ensino de Física; G: Areté; H: Práxis. 


\begin{tabular}{|c|c|c|}
\hline N.I. & Título & Referência \\
\hline 57 & $\begin{array}{l}\text { Um Estudo Metalinguístico sobre as Interpretações do Fóton nos Livros Didáticos de Física } \\
\text { Aprovados no PNLDEM 2015: Elementos para uma Sociologia Simétrica da Educação em } \\
\text { Ciências }\end{array}$ & D $18(1), 2018$ \\
\hline 58 & $\begin{array}{l}\text { O Mestrado Nacional Profissional em Ensino de Física: Investigando os Modos de } \\
\text { Regulação em um Polo Regional do Programa }\end{array}$ & D $18(2), 2018$ \\
\hline 59 & $\begin{array}{l}\text { Dificuldades e Estratégias para Compreensão do Conceito de Emaranhamento Quântico: } \\
\text { Um Estudo na Formação Inicial de Professores de Física }\end{array}$ & D 19, 2019 \\
\hline 60 & Vozes Epistemológicas e Pedagógicas nos Parâmetros Curriculares Nacionais de Biologia & E $3(2), 2010$ \\
\hline 61 & $\begin{array}{l}\text { A Perspectiva Ciência, Tecnologia e Sociedade na Formação Inicial de Professores de } \\
\text { Física: Estudando Concepções A Partir de uma Análise Bakhtiniana }\end{array}$ & E 9 (2), 2016 \\
\hline 62 & $\begin{array}{l}\text { O laboratório didático nos discursos de professores de física: heterogeneidade e } \\
\text { intertextualidade }\end{array}$ & F 26 (3), 2009 \\
\hline 63 & $\begin{array}{l}\text { A ficção científica de Júlio Verne e o ensino de física: uma análise de "Vinte mil léguas } \\
\text { submarinas" }\end{array}$ & F 30 (1), 2013 \\
\hline 64 & $\begin{array}{l}\text { Física Quântica no ensino médio: uma análise bakhtiniana de enunciados em livros } \\
\text { didáticos de Física aprovados no PNLDEM } 2015\end{array}$ & F 34 (2), 2017 \\
\hline 65 & $\begin{array}{l}\text { Fenômenos intermediários de interferência e emaranhamento quânticos: o interferômetro } \\
\text { virtual de Mach -Zehnder integrado a atividades didáticas }\end{array}$ & F 35 (1), 2018 \\
\hline 66 & $\begin{array}{l}\text { As fronteiras entre o discurso científico e a divulgação científica: uma análise de matérias } \\
\text { da revista Amazonas faz ciência }\end{array}$ & G 4 (7), 2011 \\
\hline 67 & $\begin{array}{l}\text { Alfabetização Científica: apropriações discursivas no desenvolvimento da escrita de alunos } \\
\text { em aula de Ecologia }\end{array}$ & H 5 (10), 2013 \\
\hline 68 & A Importância de Bakhtin e seu círculo no processo de comunicação científica no Brasil & H 9 (18), 2017 \\
\hline 69 & $\begin{array}{l}\text { Conhecimentos produzidos acerca da comunicação científica em Bakhtin: uma incursão } \\
\text { nas dissertações e teses brasileiras }\end{array}$ & $\begin{array}{l}\text { H } 10(19), \\
2018\end{array}$ \\
\hline 70 & $\begin{array}{l}\text { Análises multidimensional e Bakhtiniana do discurso de trabalhos de conclusão } \\
\text { desenvolvidos no âmbito de um mestrado profissional em ensino de Física }\end{array}$ & A 23 (1), 2017 \\
\hline
\end{tabular}

N.I.: número de identificação do artigo; Referência: letra que representa a revista, volume (número), ano. A: Ciência \& Educação; B: Ensaio; C: Investigações em Ensino de Ciência; D: Revista Brasileira de Pesquisa em Educação em Ciências; E: Alexandria; F: Caderno Brasileiro de Ensino de Física; G: Areté; H: Práxis. 